„Racjonalia” / nr 5 / 2015, s. 21-59

DOI: http://dx.doi.org/10.15633/r.1808

Robert Goczał

\title{
ESENCJALIZACJA PRZEDMIOTU METAFIZYKI W UJĘCIU FRANCISZKA SUÁREZA SJ ${ }^{1}$
}

Program metafizyki Suáreza zaznacza się w trzech zasadniczych punktach: 1) we wprowadzeniu do metafizyki pojęcia „bytu przedmiotowego" (ens obiectivum) i związanej z nim teorii poznania intelektualnego; 2) z koncepcją różnicy myślnej (distinctio rationis) między „istotą” a „istnieniem”; 3) w końcu, ze zdefiniowaniem „istoty” (essentia) jako adekwatnego przedmiotu metafizyki. Stanowi ona ratio entis in communi, najbardziej powszechną zasadę bytu, wykraczającą poza zróżnicowania cech istotnościowych bytów jednostkowych, która zostaje ujęta na poziomie poznania przedmiotowego (secundum se) ${ }^{2}$. Pojęcie „istoty”

1 Artykuł stanowi skróconą wersję rozdziału II: R. Goczał, Onto-teo-logia. Status bytu realnego i myślnego w metafizyce Francisco Suareza, Warszawa 2011, rozdz. II, s. 133-236.

${ }^{2},[$,...] adaequate et secundum se, quia unitas in unaquaque re seu conceptu obiectivo reali secundum propriam eius rationem attendi...Unde homo dicitur unus essentialiter, quia secundum propriam adaequatam rationem suam non est divisus in essentiali ratione, quamvis in individuis entitative dividatur; non dicetur autem homo simpliciter unus illo modo, eo quod sit indivisus in ratione animalis; ea enim indivisio non sufficeret ad praedictam unitatem, eo quod non conveniat homini adaequate et per se primo, sed ratione superioris. Ex his ergo satis explicata est ratio unitatis in communi sumpta. Ut tamen distinctius et radicitus explicetur, oportet ut de unitate individuali, formali et universali, quae sunt propriae unitates metaphysicae, in particulari dicamus" (Francisco Suárez SJ, Disputationes metaphysicae, [w:] Opera omnia, Editio nova, a Carolo Berton, t. 25-26, Parisiis: Apud Ludovicum Vivès, Bibiopolam editorem 1866, t. 25, disp. IV, sek. 8, art. 14. W dalszej części cytowane jako Disputationes metaphysicae). 
pozwala zarazem na wprowadzenie do metafizyki pojęcia jednoznacznego między wszystkimi kategoriami bytów realnych, w tym między bytem jednostkowym a bytem Boga. Świadczy to o szczególnym modelu metafizyki zesencjalizowanej u Suáreza, w której przeważa analiza ontologiczna nad istotą bytu z pominięciem analizy egzystencjalnej. Celem niniejszego artykułu jest ukazanie tej szczególnej perspektywy w systemie Suáreza, która pozwala wykazać te zależności.

\section{PROWENIENCJA NACZELNYCH POJĘĆ SYSTEMU}

Szczególną uwagę należy zwrócić na fakt, że pojęcie „esse obiectivum”, oznaczające dla Suáreza status istnienia przedmiotowego bytu w intelekcie, w ujęciu scholastycznym nie odnosi się do pozamyślnej rzeczywistości zobiektywizowanej, lecz w tym szczególnym rozumieniu wskazuje na „byt poznawczy” (esse cognitum). Pojęcie to nie służy do interpretacji rzeczywistości obiektywnej we współczesnym znaczeniu tego wyrażenia, ale do usystematyzowania i uściślenia odmian rzeczywistości poznawczej intelektu, by uniknąć niejednolitości w typach definicji odnoszących się do porządku „drugiej intencji” intelektu (secunda intentio intellectus). Dopiero między wiekiem XVII a XVIII pojęcie „obiectivus” ulega reinterpretacji w idealizmie nowożytnym, zwłaszcza za sprawą subiektywizmu teoriopoznawczego Kartezjusza († 1650) ${ }^{3}$.

Teoria „bytu” Suáreza wiąże się bezpośrednio z pojęciem „bytu przedmiotowego", jakkolwiek rozumianego odmiennie. W polu rozważań nad „bytem przedmiotowym” Suárez umieszcza pojęcie „istoty”. Podobnie jak dla Kartezjusza „idee”, „istota” znajduje się w stosunku

${ }^{3}$ Por. R. Descartes, Medytacje o pierwszej filozofii. Zarzuty uczonych mężów i odpowiedzi autora. Rozmowa z Burmanem, przeł. M. i K. Ajdukiewiczowie, S. Swieżawski, I. Dąmbska, Kęty 2001, s. 62-63, a także 94-95, 100, 105, 150-151. W sprawie uniwersaliów zob. R. Descartes, Zasady filozofii, przeł. I. Dąmbska, Kęty 2001, s. 45-46. O odmiennościach w rozumieniu „rzeczywistości przedmiotowej” między Suárezem a Kartezjuszem zob. T. Cronin SJ, Objective Being in Descartes and in Suárez, Rome 1966, zwł. s. 77-96. 
pierwszeństwa poznawczego wobec istniejącej rzeczywistości, która dopiero z perspektywy poznania „istoty” staje się bardziej zrozumiała. Zbliża to Suáreza zarówno do koncepcji bytu Awicenny († 1037), zgodnie z którą przedmiotem metafizyki jest najogólniejsze pojęcie „natury trzeciej” (natura tertia), a więc „natury wspólnej” (natura communis), jak również do koncepcji Jana Dunsa Szkota († 1308), dla którego pojęcie „bytu” sprowadza się do pojęciowego poznania „natury najogólniejszej" ${ }^{4}$. Pozostaje to również w pewnym związku z ujęciem Awerroesa († 1198), który „byt pomniejszony” (ens diminitum) traktuje jako ogólną zasadę (in genere diminitum generum entis), prawdę o bycie, która jest inteligibilnym przedmiotem intelektu ${ }^{5}$. Dopiero wyrażona w konkrecie (haecceitas) może determinować byt na sposób konkretny, jednostkowy, stanowiąc dla bytu wewnętrzny sposób bytowania (intrinsecus modus naturae individualis) ${ }^{6}$. Duns Szkot

${ }^{4}$ Por. E. Elorduy, Duns Scoti influxus in Francisci Suárez doctrinam, [w:] De Doctrina Ioannis Duns Scoti, t. 4 (Scotismus decursu saeculorum), Rome 1968, s. 307-337; P. Minges, Suárez und Duns Scotus, [w:] „Philosophisches Jahrbuch” (1919) 32, s. 334340. W sprawie różnic między Suárezem a Dunsem Szkotem, zwł. w rozumieniu „materii pierwszej", zob. A. Inaven, Suárez' Widerlegung des scotistischen Körperlichkeitsform, [w:] P. Franz Suárez Gedenkblätter zu seinem 300 Jährigen Todestag, Innsbruck 1917. Zob. także J. F. Sagües Iturralde, Escoto y la Eficacia del Concurso divino ante Suárez, [w:] De doctrina Ioannis Duns Scoti, t. 4 (Scotismus decursu saeculorum), Rome 1968, s. 339-374.

${ }^{5}$ Por. Averrois, Commentarium magnum in Aristotelis Metaphysicorum libros, [w:] tenże, Aristotelis opera cum Averrois commentariis, t. 4 (Aristotelis Metaphysicorum libri XIIII cum Averrois Cordubensis in eosdem commentariis), Venetiis: Apud Iunctas 1562 (reprint Frankfurt-am-Main 1962), ks. VIII, s. 6, c. 2, fol. 152v i 152r. Na temat struktury poznania u Awerroesa zob. R. C. Taylor, Remarks on Cogitatio in Averroes' Commentarium Magnum in Aristotelis De Anima Libros, [w:] Averroes and the Aristotelian Tradition. Sources, Constitution and Reception of the Philosophy of Ibn Rushd (1126-1198). Proceedings of the Fourth Symposium Averroicum (Cologne, 1996), ed. G. Endress, J. A. Aersten (Islamic Philosophy, Theology and Science. Texts and Studies XXXI), Leiden-Boston-Köln 1999, s. 217-255.

${ }^{6}$ F. Suárez koncepcję „bytu zmniejszonego” Dunsa Szkota przywołuje m.in. w disputatio XXXI, w której analizuje zagadnienie „istoty”: „reprehendunt Scotum, quod asseruerit, creaturas habere quoddam esse aeternum, quod est esse diminutum earum, 
przyjmuje za punkt wyjścia badania rzeczywistości Awicenniańską koncepcję „istoty” jako „natury trzeciej”, z drugiej jednak strony na oznaczenie najogólniejszego pojęcia „bytu” przyjmuje także określenie „ens omnino communissime”, co zdaje się sugerować, że w pojęciu „bytu” zawierają się wszystkie denominacje „bytu realnego”, z wyłączeniem bytów wewnętrznie sprzecznych (np. chimera czy inne impossibilia) $)^{7}$. Ponadto wskazuje on na porządek „drugiej intencji” w tym porządku intelekt poznaje byt poprzez "byt przedmiotowy”, który charakteryzuje status poznawczy bytu w intelekcie w stopniu najwyższym i niezróżnicowanym ${ }^{8}$. Należy zaznaczyć, że zarówno dla Dunsa Szkota, Awicenny i Suáreza „natura” oznacza tutaj pojęcie najogólniejsze, ratio entis bytu, zasadę, która odnosi się do wszystkich bytów, mimo zróżnicowania cech na poziomie poszczególnych indywiduów ${ }^{9}$. Dla Dunsa Szkota stanowi abstrakcyjny rezultat intelektu-

scilicet esse obiectivum seu essentiae in esse cognito" (Disputationes metaphysicae, disp. XXXI, sek. 2, art. 1). Ponadto na temat „bytu zmniejszonego" w Disputationes zob. disp. XX, sek. 1, art. 30; disp. XXXI, sek. 2, art. 1-2; disp. XXX, sek. 15, art. 27. W sprawie koncepcji „bytu zmniejszonego" u Dunsa Szkota zob. M. A. Krąpiec OP, Byt $i$ istota. Św.Tomasz „De ente et essentia”, [w:] Dzieła, t. 11, Lublin 1994, rozdz. V (Jana Dunsa Szkota koncepcja bytu), s. 167-187; W. Park, Haecceitas and the Bare Particular, [w:] „Review of Metaphysics” (1990) 44, s. 375-397.

7 Por. Joannes Duns Scoti, Quodlibeta III, [w:] Obras del Doctor Sutil Juan Duns Escoto: Cuestiones cuodlibetales, ed. Felix Alluntis (Biblioteca de Autores Cristianos, 277), Madrid 1968, s. 93-94. Zob. także O. Boulinois, Être et représentation. Une généalogie de la métaphysique moderne à l'époque de Duns Scot (XIII-XIV siècle), (Epiméthée. Essais philosophiques), Paris 1999, s. 459-462.

8 „Aliquando autem universale accipitur pro re subjecta intentioni secundae, id est, pro quiddidate rei absoluta, quae quantum est de se, nec est universalis, nec singularis, sed de se est indifferens, et tale est objectum intellectus directum; non autem est in intellectu subjective, sed tantum objective" (Joannes Duns Scotus Doctoris Subtilis, Qucestiones super libros Aristotelis De anima, [w:] tenże, Opera omnia, t. 2, ed. L. Wadding, Lyon 1639, q. 17, art. 14, 546a).

9 Por. E. Zieliński, Jednoznaczność transcendentalna w metafizyce Jana Dunsa Szkota, Lublin 1988, s. 71. Zob. także cenną pozycję, w której autorka omawia różnice stanowisk w odniesieniu do problematyki „zasady jednostkowienia”, zestawiając je z poglądami Suareza: M. Koszkało, Franciszka Suáreza koncepcja jednostkowienia bytu 
alnego ujęcia rzeczywistości na sposób przedmiotowy w intelekcie (tantum obiective), a więc na poziomie aktu „drugiej intencji”. W koncepcji Suáreza „istota” jest niezdeterminowana konkretnościowo, lecz ujmowana w stopniu najogólniejszym w porządku przedmiotowym (noetycznym). Sprawia to, że jako racja bytu - ujęta od strony analizy ontologicznej - może odnosić się w równym stopniu do bytów szczegółowych, jak i ogólnych, skończonych, jak i nieskończonych, bytu stworzonego i niestworzonego (Boga) ${ }^{10}$. Jest czymś uniwersalnym w duszy, czymś ujętym na sposób przedmiotowy. W ten sam sposób Duns Szkot ujmuje status „bytu myślnego” w intelekcie ${ }^{11}$. Ideowo najbliższym stanowiskiem dla koncepcji Suáreza jest teoria „esse obiectivum" teologa z Werony Zaccaria Pasqualiga $(† 1664)^{12}$ i szkotysty

na tle stanowisk myślicieli średniowiecznych, [w:] „Filo-Sofija” 15 (2011) 4, s. 881-897. Więcej zob. Suárez on Individuation, Metaphysical Disputation V: Individual Unity and its Principle, Translation, Introduction, and Glossary by J. J. E. Gracia, Milwaukee 1982, Ss. 229.

${ }^{10}$ Disputationes metaphysicae, disp. I (De natura primae philosophiae seu metaphysicae), sek. 1, art. 26.

${ }^{11}$ „Nec est tertio «diffinitio» entis rationis, quod est tantum ens diminutum, quia proprie quid, sicut et ens, non competit nisi enti reali. Patet 5 et 6 Meta.. Nec intelligo hic ens rationis, quod est in intellectu obiective (quia sic omne universale est in anima) nec illud quod est tantum in intellectu subiective (quia sic intellectio et scientia sunt in anima, quæ tamen sunt formæ reales, et in genere qualitatis), sed intelligo ens in anima, tamquam secundo consideratum, non tamquam primo consideratum, ad quod considerandum movetur primo anima a re extra, sed tamquam ens in primo considerato, inquantum consideratum: et tale ut in summa sit dicere, non est nisi relatio rationis: quia nihil habet præcise esse in considerato, ut considerato, nisi comparatio qua consideratum comparatur ad aliud, per actum considerantis: ens ergo diminutum, ut hic accipitur universaliter, ens ens rationis" (Joannis Duns Scoti Doctoris Subtilis, Ordinatio, IV, [w:] tenże, Opera omnia, t. 8, ed. L. Vivès, dist. 1, q. 2, art. 3, 56a-57a). Cyt. za M. Forlivesi, La distinction entre concept formel et concept objectif: Suárez, Pasqualigo, Mastri, trad. di O. Boulnois, [w:] „Les Études Philosophiques” (2002) 1, s. 5.

${ }^{12}$ Zob. Zacharia Pasqualiguus, Disputationes metaphysicae, Romae: Ex Typographia Andreae Phaei 1634, pars I (De conceptu entis), disp. XXXIII (An conceptus formalis entis sit unus), sek. 1 (Aliorum sentential), 263b-264a. W sprawie koncepcji „bytu przedmiotowego" u Zaccaria Pasqualigo zob. M. Forlivesi, La distinction entre con- 
Bartolomea Mastri da Meldola $(† 1673)^{13}$, jak również teoria „drugich aktów intelektualnych duszy" biskupa Clermont Piotra z Owernii (Petrus de Alveria) († 1304) $)^{14}$ oraz teoria „aktów duszy” Jakuba z Ascoli OFM (Jacobus de Aesculo, de Aesquillo). Jakub z Ascoli wyrażeń: „esse obiectivum”, „esse obiective”, „esse inteligibile” czy „esse repraesentantum", używa w jednym znaczeniu ${ }^{15}$.

cept formel et concept objectif: Suárez, Pasqualigo, Mastri, trad. di O. Boulnois, „Les Études Philosophiques" 57 (2002), s. 3-30. Na temat życia i filozofii Zaccaria Pasqualigo zob. Antonio Francesco Vezzosi, I scrittori de' Chierici regolari detti Teatini, II, Roma 1780 o, s. $156-161$.

${ }^{13}$ Zob. Bartholomaeus Mastrius, Disputationes in organum Aristotelis, Venetiis: Typis Marci Ginammi 1646, disp. X, q. II (An veritas sit in conceptu formali vel obiectivo), art. 6, 765a. W tej sprawie zob. również Leen Spruit, Species intelligibilis. From Perception to Knowledge, Leiden-New York-Köln 1995, s. 345-346. Na temat życia i filozofii Bartolomea Mastri zob. J. Coombs, The Possibility of Created Entities in Seventeenth-Century Scotism, „The Philosophical Quarterly” 43 (1993), s. 447-459; M. Forlivesi, Circolo e artificio. La natura della metafisica secondo Bartolomeo Mastri, Milano (à paraître) 2001/2002; T. Hoffmann, Creatura intellecta. Die Ideen und Possibilien bei Duns Scotus mit Ausblick auf Franz von Mayronis, Poncius und Mastrius, Diss. Freiburg (Schweiz) 1999.

${ }^{14}$ Por. G. Cannizzo, La dottrina del «verbum mentis» in Pietro di Auvergne. Contributo alla storia del concetto di intenzionalità, „Rivista di Filosofia Neo-Scolastica” 53 (1961), s. 152-168.

${ }^{15}$ Por. Jacobus de Aesculo, Zwei Quaestiones des Jacobus de Aesculo über das Esse Obiectivum (Quaestiones ordinariae), ed. T. Yokoyama, [w:] Wahrheit und Verkündigung, I, op. L. Scheffczyk, W. Detthof, R. Heinzmann, München-PaderbornWien 1967, s. 31-74; Z. Włodek, Zagadnienie "esse obiectivum” $i$ intelektu u Jakuba $z$ Ascoli, „Studia Mediewistyczne” 6 (1964), s. 3-18. Nie jest znana data narodzin ani śmierci Jakuba z Ascoli. Najstarsze podania informują, że był on jednym z magistrów teologii w Paryżu ok. 1309 roku. Został uhonorowany tytułem Doctor Profundus. W latach 1311-1312 przeprowadził dysputę de quodlibet. Ponadto wiadomo, że był uczestnikiem soboru wienneńskiego (1311-1312), który papież Klemens V zwołał na polecenie króla Filipa Pięknego, głównie w sprawie nowej wyprawy krzyżowej i zakonu rycerskiego templariuszy. W wyniku obrad 22 marca 1312 roku zakon uległ kasacie na mocy papieskiego rozporządzenia administracyjnego. Ponadto istnieją wzmianki, na podstawie których komentatorzy wnioskują, że Jakub z Ascoli był przeciwnikiem Dunsa Szkota. 
To bardzo ogólne, przedmiotowe pojęcie „istoty” umożliwia wgląd w intelektualną poznawalność natury „bytu”. Wskazuje, że sama istota jest „bytem możliwym” (possibile esse), warunkującym istnienie wszystkich bytów. Biorąc pod uwagę powyższe, można zgodzić się ze stanowiskiem, zgodnie z którym zarówno koncepcję Awicenny, jak i Dunsa Szkota należy uznać za scholastyczną teorię, która mogła w istotny sposób zaważyć na przyszłych doktrynach monistycznego wyjaśniania rzeczywistości ${ }^{16}$. Mogła ona również zaważyć na esencjalistycznym podejściu do problematyki bytu, w której wyraźnie przeważa ontologiczna analiza bytu jako bytu możliwego ${ }^{17}$. Z pewnością mogła zaciążyć na perspektywie poznawczej „bytu jako istoty ogólnej” w metafizyce Suáreza, co wyraźnie wskazuje na esencjalizację przedmiotu metafizyki $i^{18}$. Pojęcia „istoty najogólniejszej” u Suáreza nie należy rozumieć, jakoby „natura wspólna” istniała w sposób realny poza intelektem $^{19}$. Przeciwnie, „natura wspólna”, innymi słowy uprzedmiotowione pojęcie „istoty”, jest tylko przedmiotem poznania intelektualnego natury wspólnej wszystkim bytom jednostkowym ${ }^{20}$, a nie konkretną własnością bytów. Nauka o „bycie przedmiotowym” u Suáreza nie jest na-

${ }^{16}$ M. A. Krąpiec OP, Byt i istota..., dz. cyt., s. 186.

17 Por. L. Honnefeld, La métaphysique comme science transcendantale, trad. di I. Mandrella i in. (Chaire Étienne Gilson), Paris 2002, s. 80-84.

${ }^{18}$ Podejście esencjalistyczne do metafizyki Suáreza przeważa wśród większości komentatorów, zwł. współczesnych badaczy ze Stanów Zjednoczonych, choć nie musi to być stanowisko przesądzające o wiodących interpretacjach. W celu zapoznania się z odrębnym ujęciem zob. S. Ziemiański SJ, Czy Suárez byt esencjalistą?, [w:] Oblicza filozofii XVII wieku, red. S. Janeczek, Lublin 2008, s. 513-525, lub tenże, Was Suárez essentialist?, „Studies in Logic, Grammar and Rhetoric” 15 (28) (2009), s. 9-23.

19 „Ad fundamenta contraria, posita in secunda sectione, iam declaratum est quomodo natura in re sit communicabilis multis, non per aliquam aptitudinem seu indifferentiam quae ipsi naturae secundum se conveniat, sed solum per non repugnantiam ipsarum rerum singularium ut habere possint alia sibi similia, quae non repugnantia non satis est ad rationem universalis, ut declaratum est" (Disputationes metaphysicae, disp. VI, sek. 5, art. 3).

${ }^{20},[. .$.$] omnia illa attributa dicere aliquo modo ordinem ad intellectum; fundantur$ autem in rebus ipsis, non quatenus in ipsis natura habet aliquam universalitatem, sed 
uką, która zmierza do zdefiniowania natury bytów jednostkowych czy uniwersaliów, ale do uchwycenia w ogólnym pojęciu „przedmiotowym” istoty bytu w ogóle ${ }^{21}$. Należy ponadto wspomnieć, że na kształt koncepcji „bytu” w metafizyce Suáreza w nie mniejszym stopniu wywarł wpływ pogląd na temat „bytu przedmiotowego” Piotra da Fonseki SJ ${ }^{22}$. Koncepcja Suáreza jest również zbliżona w wielu zasadniczych punktach do stanowiska Gabriela Vásqueza SJ († 1604), który był jego nieustępliwym adwersarzem w wielu kwestiach natury teologicznej i filozoficznej. Dzięki zdumiewającej erudycji Vásquez zjednał sobie uznanie papieży Grzegorza XIV i Leona III. Pomimo licznych odmienności między Suárezem a Vásquezem, w badaniu struktury „bytu przedmiotowego” nie można wskazać między nimi zasadniczych różnic ${ }^{23}$. Warto wspomnieć,

quatenus in ipsis individuis est convenientia et similitudo in essentia et proprietatibus eius $[\ldots] "$ (tamże).

21 „Et hoc modo dicitur esse scientia de universalibus et non de singularibus, non quia sit de nominibus communibus, sed quia est de conceptibus obiectivis communibus, qui, licet in re ipsa non distinguantur a singularibus, distinguuntur tamen ratione et hoc satis est ad omnes locutiones praedictas" (tamże).

${ }^{22}$ Por. E. J. Ashworth, Petrus Fonseca on objective concepts and the analogy of Being, [w:] Logic and the Workings of the Mind. The Logic of Ideas and Faculty Psychology in Early-Modern Philosophy, ed. P. A. Easton, Atascadero, California 1997, s. 47-63. Więcej na temat badań nad koncepcją „bytu” u P. Fonseki zob. K. Gryżenia SDB, Arystotelizm i Renesans. Filozofia bytu Piotra Fonseki, Lublin 1995. Autor wielokrotnie przywołuje postać Suáreza i określa wpływ poglądów Fonseki na jego filozofię.

${ }^{23}$ Por. R. Dalbiez, Les sources scolastiques de la théorie cartésienne de lêtre objectif. A propos du Descartes de M. Gilson, „Revue d'Histoire de la Philosophie” (1939) 3, s. 464472. Na temat różnic między Vásquezem a Suárezem zob. R. De Scorraille, dz. cyt., s. 168171, oraz ks. II, rozdz. V (Francisco Suárez y Gabriel Vázquez), s. 269-296; M. Quera, La contrición en la justificación según Suárez y Vásquez, „Estudios Eclesiásticos” (1948) 22, s. 561-569; R. Specht, Zur Kontroverse von Suárez und Vásquez über den Grund der Verbindlichkeit des Naturrechts, "Archiv für Rechts und Sozialgeschichte” 45 (1969), S. 235-255; E. Elorduy, La predestinación en Suárez. Controversias con Vásquez, Salas y Lesio, „Archivo Teológico Granadino” 10 (1947), s. 5-151. Tekst dotyczy głośnej debaty odnoszącej się również do Juana de Salas SJ (†1612) (autora Comentarii in secundam secundae D. Thomae de contractibus, Sumptibus Horatij Lardon, Lyon 1617) oraz do jezuity Leonarda Lesio SJ (autora De iustitia et iure, Lovanii 1605); U. Baldini, Ontology and 
iż Vásquez wraz z dwoma innymi scholastykami (uczniami: Louis'em de Torres SJ († 1655) i Diego de Alarcónem SJ († 1634) przyczynił się do zawiązania własnej szkoły i zapoczątkowania jednego z większych sporów teologicznych epoki, do jakiego doszło między zakonem dominikanów i zakonem jezuitów, głównie ze względu na wyróżniony w nim aspekt dotyczący „łaski”, „wiedzy Boskiej” i „idei Bożych”.

Wśród komentatorów pojawia się także hipoteza, która wskazuje na mocne zakorzenienie metafizyki Martina Heideggera († 1976) w scholastycznej koncepcji „istoty”, pojętej jako „sens bytu” (Sinn des Seins). Heidegger był pod wyraźnym wpływem koncepcji „bytu” Dunsa Szkota, co w istocie może sugerować pewne inklinacje $\mathrm{e}^{24}$. Można tu jeszcze wskazać na pojęcie „intencjonalności” u św. Tomasza († 1274), które również może zbliżać do rozumienia „bytu przedmiotowego” u Suáreza w perspektywie noetycznej. Podobnie jak Duns Szkot, św. Tomasz wskazuje na pojęcie intencjonalne „bytu zmniejszonego” lub „niekompletnego" (ens diminutum, ens incompletum), bądź „bytu medialnego” (ens in via et quasi medium quid in potentiam puram et actum purum), który może oznaczać pojęcie „bytu intencjonalnego”, a nawet „bytu przedmiotowego" ${ }^{25}$. W istocie, św. Tomasz wspomina o bycie ogólnym, który

mechanics in Jesuit scholasticism: the case of Gabriel Vázquez, [w:] Scientiae et artes. Die Vermittlung alten und neuen Wissens in Literatur, Kunst und Musik, ed. B. Mahlmann-Bauer, Wiesbaden 2004, s. 99-142. Zob. także N. J. Wells, John Poinsot on created eternal truth vs. Vasquez, Suárez and Descartes, "The American Catholic Philosophical Quarterly" 68 (1994), s. 425-446. Również Błażej Pascal († 1662) wspomina Suáreza i Vásqueza pośród licznych autorytetów zakonu jezuitów, którzy nierzadko pozostawali w opozycji poglądowej. Por. Pascal, Prowincjałki, przeł. T. Żeleński-Boy, Warszawa 1963, s. 77, 84-85, 91, 127, 129, 157, 161, 161, 164, 167, 169, 191-194, 217-220.

${ }^{24}$ M. A. Krąpiec, Byt i istota..., dz. cyt., s. 186-187.

${ }^{25}$ „Si dicatur, quod illa differentia est eadem secundum speciem in utroque, sed differens numero, contra: quidquid est ejusdem speciei, non dividitur secundum numerum, nisi secundum divisionem materiae vel alicujus potentialitatis. Ergo et illa differentia est eadem secundum speciem, differens numero. Oportebit ergo quod in Deo sit aliquid potentiale, et sic ens diminutum et dependens ad aliud, quod est contra rationem primi entis" (Sancti Thomae Aquinatis, Scriptum super Sententiis magistri Petri Lombardi, t. 1, ed. P. Mandonnet, Parisiis: P. Lethielleux 1929, ks. I, dist. II, q. 1, art. 1, 
jest bytem „drugiej natury”, wytworzonym poprzez aktualizację nabytych treści w świadomości. W wypadku człowieka byt ten całkowicie zawiera się w intencjach duszy. Przykładem takiego „bytu zmniejszonego" może być np.: „potencjalna siła narzędzia” (zawarta w narzędziu nie mocą istoty, lecz na mocy przyczyny sprawczej aktu/intencji działania), „postać barwy w powietrzu” (wywoływana mocą zewnętrznego istnienia przedmiotów barwnych), w końcu „species” (jako forma poznawcza aktualizująca intelektualną władzę duszy) ${ }^{26}$. Św. Tomasz wskazywał na dwojaki status ontologiczny bytów intencjonalnych: „mniej” i „bardziej doskonały”, co w pewnym stopniu może zbliżać jego teorię do koncepcji Suáreza, który wprowadza w obszar intencjonalności pojęcie „bytu formalnego" i „przedmiotowego", a następnie w porządku przedmiotowego istnienia umieszcza „byt myślny”27. Pojęcie „bytu zmniejszonego" (ens diminutum) stosuje także brytyjski teolog i filozof Walter Burley († ok. 1344), który wywarł ogromny wpływ na kształtowanie się XIV-wiecznego nominalizmu. Wykazał on, że „byt zmniejszony” jest intencjonalnym korelatem danych oznaczeniowych (significata), z których tworzony jest byt prawdy w intelekcie (veritas in intellectu), korespondujący intencjonalnie z bytem rzeczy (veritas rei $)^{28}$. Reinterpretację to-

s. c. 3). Więcej na ten temat zob. A. Maurer CSB, Ens Diminutum: a Note on its Origin and Meaning, "Mediaeval Studies” 12 (1950), s. 216-222.

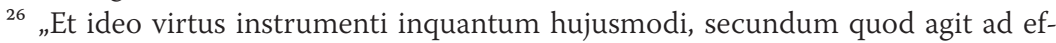
fectum ultra id quod competit sibi secundum suam naturam, non est ens completum habens esse fixum in natura, sed quoddam ens incompletum, sicut est virtus immutandi visum in aere, inquantum est instrumentum motum ab exteriori visibili; et hujusmodi entia consueverunt intentiones nominari, et habent aliquid simile cum ente, quod est in anima quod est ens diminutum, ut dicitur in 6 Metaph" (Sancti Thomae Aquinatis, Scriptum super Sententiis magistri Petri Lombardi, t. 4. ed. M. F. Moos, Parisiis: P. Lethielleux 1947, ks. IV, dist. I, q. 1, art. 4, qc. 2).

${ }^{27}$ „Et ideo recte definiri solet ens rationis esse illud, quod habet esse obiective tantum in intellectu" (Disputationes metaphysicae, disp. LIV, sek. 1, art. 6). Zob. również A. Maurer, Ens Diminutum..., dz. cyt., s. 219-220.

${ }^{28} \mathrm{~W}$. Burley, Commentarium in librum Perihermeneias (1310 env.), ed. Stephen F. Brown, Walter Burley's Middle Commentary on Aristotle's Perihermeneias (Commentary medius), „Franciscan Studies” 33 (1973), s. 6o-61 (więcej 42-134). 
mistycznej koncepcji „intencjonalności” podjął w XIV wieku Wilhelm Ockham († ok. 1350), rzecznik nominalizmu zaliczany do prekursorów "nowej drogi” (via moderna). W noetyce przedmiotów intencjonalnych, podobnie jak Awerroes, przyjął stanowczy pogląd. Według Ockhama bytom intencjonalnym, wszelkim przedmiotom intelektualnym, czy to skonceptualizowanemu pojęciu „bytu realnego”, „bytu przedmiotowego”, „naturom ogólnym” („powszechnikom”), czy pojęciu „bytu myślnego” nie należy przydawać pozorów rzeczywistości. Realnie istnieją tylko byty jednostkowe, konkrety ${ }^{29}$. Ockham wprowadza ponadto podział między esse subiectivum i esse obiectivum. Wszystkie uniwersalia, jak również byty myślne posiadają w intelekcie poznającym status „istnienia przedmiotowego" (esse obiectivum), natomiast byty realne, posiadające realny status istnienia poza intelektem (extra intellectum), posiadają w poznaniu status „istnienia podmiotowego” (esse subiectivum) ${ }^{30}$. Skądinąd

${ }^{29}$ Ockham omawia problematykę „uniwersaliów” w następujących miejscach: Guillelmi de Ockham, Venerabilis inceptoris Guillelmi de Ockham Scriptum in librum primum Sententiarum. Ordinatio, [w:] tenże, Opera philosophica et theologica, cura Instituti Franciscani, Universitatis S. Bonaventurae, Opera theologica, t. 2, ed. G. Gál OFM, New York 197o, I, dist. 2, q. 4-8; Summa logicae, [w:] tenże, Opera philosophica et theologica, cura Instituti Franciscani, Universitatis S. Bonaventurae, Opera philosophica, t. 1, ed. Ph. Boehner OFM, Gedeon Gál OFM, S. Brown, New York 1974, I, XV-XVII; Quodlibeta Septem, [w:] tenże, Opera philosophica et theologica, cura Instituti Franciscani, Universitatis S. Bonaventurae, Opera theologica, t. 9, ed. J. G. Wey, New York 1980, q. 12-13; Expositionis in Libros Artis Logicae Prooemium et Expositio in Librum Porphyrii de Praedicabilibus, [w:] tenże, Opera philosophica et theologica, cura Instituti Franciscani, Universitatis S. Bonaventurae, Opera philosophica, t. 2, ed. Ph. Boehner OFM, G. Gál OFM, S. Brown, New York 1978, praefatio.

${ }^{30}$ „Intellectus noster primo intelligi intuitive aliquid singulare realiter existens, quo intellecto potest idem intellectus fingere aliquid consimile prius intellecto, sed illud fictum non poterit habere esse subjectivum, sed tantum esse objectivum [...] et ideo illud sic fictum est tantum tale, quale fuit prius intellectum in esse objectivo et non est in esse subjectivo, sed erit quasi imago simillima rei prius intellectae in esse objectivo [...]" (Guillelmi de Ockham, Scriptum in libros Sententiarum seu Ordinatio, [w:] tenże, Opera philosophica et theologica, cura Instituti Franciscani, Universitatis S. Bonaventurae, Opera theologica, t. 3, ed. Ph. Boehner OFM, G. Gál OFM, S. Brown, New York 1977, I, dist. 13, q. 1); „Universale non est aliquid reale habens esse subjecti- 
znane są wystąpienia Ockhama przeciwko arabsko-łacińskiemu arystotelizmowi, który w zagadnieniach z zakresu fizyki postulował aprioryczne rozstrzygnięcia, gdy ich rezultaty poznawcze wyraźnie kontrastowały z doświadczeniem ${ }^{31}$.

Rozważania nad koncepcją „bytu” Suáreza wskazują z jednej strony na teorię interesującą pod względem historycznym, z drugiej sugerują, że może ona stanowić pogłębione studium wcześniejszych teorii scholastycznych. U Suáreza spotykamy się z teorią, która w sposób oczywisty wpłynęła na epistemologię nowożytną i postkartezjańską filozofię podmiotu jako poznawczego zwrotu ku sobie (in se conversa). Refleksja nad bytem realnym została w tej teorii przesunięta w stronę treści o charakterze reprezentacji podmiotowo-świadomościowych, w stronę refleksji noetycznej, w stronę mentalizmu ${ }^{32}$. Ten szczególny proces zmiany perspektywy poznawczej jest nazywany również „przejściem od metafizyki do ontologii”" ${ }^{33}$.Zaważyło to na wyraźnym przesu-

vum nec in anima nec extra animam, sed tantum habet esse objectivum in anima et est quoddam fictum habens esse tale in esse objectivo, quale habet res extra in esse subjectivo" (tamże, I, dist. 2, q. 8).

${ }^{31}$ Por. S. Swieżawski, Studia z myśli późnego średniowiecza, Warszawa 1998, s. 97-98; S. Swieżawski, Dzieje europejskiej filozofii klasycznej, Warszawa-Wrocław 2000, s. 817-819; E. Gilson, Historia filozofii chrześcijańskiej w wiekach średnich, przeł. S. Zalewski, Warszawa 1987, s. 437; Guillelmi de Ockham, Expositio in Librum Perihermeneias Aristotelis, ed. A. Gambates, S. Brown, [w:] Opera Philosophica, t. 2, New York 1978, s. 23-34.

${ }^{32}$ Por. J. E. Gracia, Suárez's Conception of Metaphysics: A Step in the Direction of Mentalism?, „American Catholic Philosophical Quarterly” 65 (1991), s. 287-309, zwł. 291-294; tenże, Suárez and Metaphysical Mentalism: The Last Visit, „American Catholic Philosophical Quarterly” 67 (1993), s. 349-354. Na temat refleksji wewnętrznej u Kartezjusza zob. W. Chudy, Rola refleksji w dziedzinie „cogito” Descartesa, „Roczniki Filozoficzne” 30 (1980), z. 1, s. 33-58. Na temat typów refleksji "in actu signato" i „in actu exercito" zob. również B. Paź, Epistemologiczne założenia Christiana Wolffa, Wrocław 2002, s. 37-47.

${ }^{33}$ Więcej na ten temat i o roli, jaką w tym procesie spełnił Suárez, zob. E. M. Rompe, Die Trennung von Ontologie une Metaphysik. Der Ablösungsprozess und seine Motivierung bei Benedictus Pererius und anderen Denkern des 16. und 17. Jahrhunderts (dysertacja), Bonn 1968; J.-P. Coujou, Suárez et la refondation de la métaphysique comme 
nięciu teoretycznym w refleksji nad bytem w ponowożytnych nurtach filozoficznych. Między innymi wywarło pośredni wpływ na: kantowską rewolucję filozoficzną (przejście w stronę krytyki transcendentalnej), filozofię transcendentalnego idealizmu George‘a. W. F. Hegla i fenomenologię Edmunda Husserla, wreszcie na subiektywistyczny egzystencjalizm Jean-Paul Sartre'a († 1980), francuskiego filozofa, jednego z głównych przedstawicieli egzystencjalizmu, który podjął się reinterpretacji teorii cogito Kartezjusza oraz krytyki filozofii transcendentalnej Kanta i Husserla ${ }^{34}$. W tej sytuacji nietrudno zauważyć, że problematyka określania czynników apriorycznych w poznaniu, która u Suáreza zasadza się na przeformułowaniu doświadczenia poznawczego i ustanowieniu w metafizyce teorii „bytu przedmiotowego" w intelekcie - w odróżnieniu od „bytu realnego”, byt przedmiotowy jest ujmowany aktem refleksji in actu signato (podmiotowo-uprzedmiotawiającej) $)^{35}$ - była szczególnie żywo dyskutowaną kwestią już w XVII-wiecznej scholastyce odrodzeniowej, wyraźnie obecną w Disputationes metaphysicae.

Otóż zasadniczą koncepcją, która pozwala Suárezowi na wypracowanie teorii „bytu”, jest uprzednie zdefiniowanie płaszczyzny poznania

ontologie: étude et traduction de l'Index détaillé de la Métaphysique d'Aristote de F. Suárez, Louvain 1999, Ss. 242. Praca zawiera obszerną bibliografię (s. 225-240). O pewnym rozumieniu różnicy między metafizyką a ontologią zob. A. Stępień, Metafizyka a ontologia, „Roczniki Filozoficzne” 7 (1959), z. 1, s. 85-99.

${ }^{34}$ Por. M. A. Krąpiec OP, Byt $i$ istota..., dz. cyt., s. 54, 76, 154. W sprawie rozumienia "cogito" u J.-P. Sartre’a zob. B. Paź, Cogito, [w:] Powszechna encyklopedia filozofii, t. 2, red. A. Maryniarczyk, Lublin 2001, s. 244-247; S. Schindler, Consciousness in Satisfaction as the Prereflective Cogito, "Process Studies” 5 (1975) nr 3, s. 187-19o. Ponadto na temat przesunięcia w nowożytności perspektywy poznawczej zob. również: A. Maryniarczyk SDB, Transcendentalia w perspektywie historycznej. Od arché do antytranscendentaliów, [w:] Św. Tomasz z Akwinu, De veritate. O prawdzie, przekł. A. Białek, tekst poprawili M. A. Krąpiec OP, A. Maryniarczyk SDB, Lublin 1999, s. 136-139 (W kierunku antytranscendentaliów).

35 „Deinde dicitur, esto scientia non consideret existentiam rei in actu exercito, considerare tamen illam in actu signato [...]" (Disputationes metaphysicae, disp. I, sek. 5 , art. 40 ). 
przedmiotowego, z czym wiąże się teoria „bytu przedmiotowego” (esse

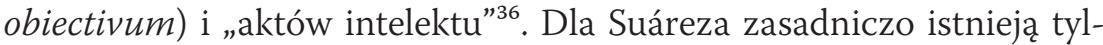
ko dwie kategorie „bytu”: „byt realny”, który posiada wiele desygnatów, i „byt myślny”, który jest bytem w pełni zależnym od refleksji intelek$\mathrm{tu}^{37}$. Jedynie „byt realny” jest bezpośrednim, adekwatnym przedmiotem metafizyki, podczas gdy „byt myślny” stanowi jedynie dopełnienie tej nauki, stając się koncepcją regulatywną w ramach niektórych rozstrzygnięć systemowych ${ }^{38}$. Teoria „bytu przedmiotowego”, która niejako unifikuje w obrębie poznania realnego wszystkie analogiczne względem pojęcia „bytu” denominacje ${ }^{39}$, jest zarazem kontekstem, który pozwala Suárezowi na zdefiniowanie relacji poznawczej rzeczy w stosunku do intelektu poznającego. Suárez teorię „bytu przedmiotowego” sytuuje w obszarze teorii „pierwszych” i „drugich intencji” intelektu (primae et secundae intentionis), która to teoria wydaje się stanowić podstawę całego rozumowania w obrębie ontologii bytu ${ }^{40}$. Koncepcja „intencji po-

36 Zob. E. Elorduy, El concepto objectivo en Suárez, „Pensamiento” 4 (1948), s. 335-423, oraz R. Darge, Ens in quantum ens: Die Erklärung des Subjekts der Metaphysik bei F. Suárez, „Recherches de Théologie et Philosophie Médiévales” 66 (1999), s. 335-361.

37 „Secundo responderi potest, de ente dupliciter posse nos loqui: uno modo, ut comprehendit tantum vera entia realis, et illa omnia transcendit et sub se continet. Alio modo, ut extenditur ad multa, quae vere et intrinsece entia non sunt, solumque per quamdam attributionem extrinsecam entia dicuntur, ut sunt privationes, vel entia omnino per accidens aut rationis" (F. Suárez, A Commentary on Aristotle's Metaphysics (Index locupletissimus in Metaphysicam Aristotelis), Translated from the Latin with an Introduction and Notes by J. P. Doyle, wyd. łac.-ang., Milwaukee 2004, liber IV, caput II, questio 2. Dalej cytowane jako Index locupletissimus, z podziałem na l. /liber/, c. /caput/ i q. /questio/).

38 „[...] unde satis expresse plura numerat, quae vera entia non sunt, ut privationes et similia, quae ipsemet excludit ab objecto metaphysicae, directo, scilicet, et adaequato $[\ldots] "$ (tamże).

$39, \ldots[.$.$] in priori enim cum adaequatum objectum metaphysicae constituat, agit de$ ente secundum proprium ejus conceptum objectivum; in hoc vero capite agit de tota amplitudine significationis nominis entis [...]" (tamże).

40 Zob. Disputationes metaphysicae, disp. II, sek. 1-2. Zob. również opracowania M. Forlivesi, La distinction entre concept formel et concept objectif: Suárez, Pasqualigo, Mastri, trad. di O. Boulnois, „Les Études Philosophiques” (2002) 1, s. 3-30; J. Hellín, 
znawczych” jest bliska teorii „pierwszych” i „drugich intencji” intelektu Dunsa Szkota, Wilhelma Ockhama i Pawła z Wenecji $(† 1428)^{41}$.

\section{RÓŻNICA MIĘDZY „ISTNIENIEM PRZEDMIOTOWYM”}

A „ISTNIENIEM POZNAWCZYM"

Przy definiowaniu pojęcia „bytu przedmiotowego” Suárez wprowadza ostre rozgraniczenie między „istnieniem przedmiotowym” (esse obiectivum) a „istnieniem poznawczym” (esse cognitum) ${ }^{42}$. Rozróżnienie to jest bardzo ważne, albowiem status istnienia „przedmiotowego” może odnosić się w tym samym stopniu zarówno do „bytów realnych”, jak i „myślnych”. Te ostatnie jednak całą swoją rzeczywistość przedmiotową posiadają tylko w „bycie poznawczym” intelektu (esse cognitum intellectus) i odwrotnie, całą rzeczywistość poznawczą w „bycie przedmiotowym"43. Należy zatem odróżnić podawane przez Suáreza typy definicji i wnioskowań, względnie wskazać warunki, na podstawie któ-

El concepto formal en Suárez, „Pensamiento” 18 (1962), s. 407-432; N. J. Wells, „Esse cognitum” and Suárez Revisited, „American Catholic Philosophical Quarterly” 67 (1993), s. 339-348. Zob. także A. Maryniarczyk SDB, Transcendentalia w perspektywie..., dz. cyt., s. $130-133$.

${ }^{41}$ Por. S. Swieżawski, Les intentions premières et les intentions secondaires chez Jean Duns Scotus, „Archives d'Histoire Doctrinale et Littéraire du Moyen Âge” 9 (1934), s. 205-26o; W. Ockham, Suma logiczna, przeł. T. Włodarczyk, Warszawa 1971, ks. I, rozdz. 2, s. 55-58; Paulus Venetus, Logica Parva, First Critical Edition from The Manuscripts with Introduction and Commentary, transl. and ed. by A. R. Perreiah, Leiden-Boston-Köln 2002, rozdz. 2 (On Supposition), sek. 2 (Material and Personal Supposition), albo wydanie Münich 1984, s. 144-147. Na temat „drugich intencji” w średniowieczu zob. A. D. Conti, Second Intentions in the Late Middle Ages, [w:] Medieval Analysis in Language and Cognition, ed. S. Ebbesen, R. Friedmann, Copenhagen 1999, S. $453-470$.

${ }^{42}$ Zob. także N. J. Wells, „Esse cognitum” and Suárez Revisited, „American Catholic Philosophical Quarterly" (1993) 67, s. 339-348.

${ }^{43}$ „[...] quae vocantur entia rationis, quia solum habent esse obiective in intellectu" (Disputationes metaphysicae, disp. II, sek. 1, art. 1). W innym miejscu Suárez wpro- 
rych można uchwycić różnicę między strukturą „bytu czysto-myślnego” a bytu charakteryzującego się „istnieniem poznawczym”. Ten ostatni bowiem determinuje status wszystkich bytów, które stają się przedmiotem intelektu poznającego, również bytów realnych.

Otóż Suárez proponuje dwie definicje „bytu poznawczego”. Po pierwsze, oznacza on byt ujęty na płaszczyźnie poznania przedmiotowego, która determinuje w statusie bytowym wszystko, co jest przedmiotem poznania intelektu. W tym rozumieniu pojęcie "bytu poznawczego" jest wieloznaczne. Może się odnosić zarówno do „bytów realnych”, jak i „myślnych” (w tym „fikcyjnych”), o ile każdy z nich staje się przedmiotem $\mathrm{w}$ intelekcie ${ }^{44}$. Po drugie, pojęcie to wskazuje na "byt”, który jest istotowo, całkowicie określony przez status istnienia przedmiotowego. Istnieje zatem o tyle, o ile jest „bytem” w poznaniu ${ }^{45}$. Dochodzi tu do wyrażenia cech istotnościowych danego „bytu”, dla którego istnienie na sposób przedmiotowy w intelekcie jest jedyną formą istnienia ${ }^{46}$. Istnienie czerpie on z czystego intelektu poznającego (esse cognitum quoad denominationem), podczas gdy w innym wypadku „byt poznawczy” posiada zapośredniczenie w bycie rzeczy realnej, która stanowi dla niego podstawę denominacji (esse cognitum quoad rem denominatum) ${ }^{47}$. W wypadku „bytu realnego”, intelekt formuje adekwatne pojęcia „bytu poznawczego", aby przez jego noematyczną zawartość, konstrukcję oraz

wadza jedność między „bytem przedmiotowym” a „poznawczym”. Zob. Disputationes metaphysicae, disp. XXIII, sek. 4, art. 11 i sek. 8, art. 8; disp. LIV, sek. 1, art. 7.

$44,[. .$.$] esse autem objective in intellectu, non solum veris entibus, sed etiam fictis$ convenire potest" (tamże, disp. VI, sek. 7, art. 2).

45 „Secundo, deficit illa evasio, quia in rigore falsum est denominationem sumptam ab actu directo intellectus habere tantum esse obiective in intellectu, nam proprie potius habet esse formale in intellectu quam obiectum. Unde cavenda est aequivocatio, quando agimus de esse cognito, aut aliis similibus denominationibus intellectus. Potest enim vocari esse cognitum, illud esse quod cognoscitur, quodque proprie est obiective in intellectu; vel potest vocari esse cognitum [...]" (tamże, disp. LIV, sek. 2, art. 13).

46 „[...] ens rationis non habere esse nisi obiectivum in intellectu” (tamże, disp. LIV, sek. 2, art. 2).

${ }^{47}$ Por. tamże, disp. XXV, sek. 1, art. 31-32; disp. XXIII, sek. 8, art. 5-8. 
podział przedmiotowy (np. na pojęcia uniwersalne, jednoznaczne, analogiczne) formować sądy ogólne i twierdzenia, chcąc uchwycić w tych momentach poznawczych samą rzeczywistość. Pojęcia te można następnie rozpatrywać z perspektywy „intencji poznawczych”, które pozwalają na adekwatne zdefiniowanie ich statusu ontologicznego. Pojęcie bowiem „bytu poznawczego”, które odnosi się do realności formalnej „pierwszej intencji”, jest zawsze zapośredniczone w „bycie realnym” ${ }^{48}$. Taki byt zawsze posiada wewnętrzną inteligibilność oraz aktualną bądź możliwą „realność”, której nie posiada byt „czysto-poznawczy”, „czysto-myślny” ". Ta operacja, która przekształca „byt realny” w „byt poznawczy”, „przedmiotowy”, w istocie dotyczy konstrukcji pojęć związanych z faktem intelektualnego poznania rzeczy ${ }^{50}$. Mianowicie, sądy czy pojęcia „przedmiotowe” - jako konstrukcje mentalne intelektu poznającego - stanowią podmiotowe elementy aktów psychiczno-intelektualnych człowieka, które w poznaniu zawsze przybierają postać przedmiotowych reprezentacji. Innymi słowy, akty te są pewnym rodzajem jakości, wynikiem dyspozycji poznawczych intelektu, które ujawnia ludzkie myślenie. $\mathrm{Z}$ drugiej jednak strony - jako przedmioty w intelekcie poznającym -

48 „[...] vel potest vocari esse cognitum, illudmet esse quod res habere dicitur, ex eo praecise quod cognoscitur, quod ex vi cognitionis directae non est obiective in intellectu, sed potius est formaliter ab actu quo res cognoscitur, obiective autem est in cognitione reflexa, qua intellectus cognoscit se cognoscere" (tamże, disp. LIV, sek. 2, art. 13).

49 "Id autem, quod sic est obiective in mente, interdum habet vel potest habere in se verum esse reale, secundum quod rationi obiicitur, et hoc absolute et simpliciter non est verum ens rationis, sed reale, quia hoc esse est quod simpliciter per se convenit, obiici autem rationi est extrinsecum et accidentale. Aliquid vero interdum obiicitur seu consideratur a ratione, quod non habet in se aliud reale ac positivum esse praeterquam obiici intellectui seu rationi de illo cogitanti, et hoc propriissime vocatur ens rationis, quia est aliquo modo in ratione, scilicet, obiective, et non habet alium nobiliorem aut magis realem essendi modum..." (tamże, disp. LIV, sek. 1, art. 6).

${ }^{50}$ „Et praeterea, licet respectu talis cognitionis illud esse sit obiective in intellectu, non tamen est tantum obiective, quia forma, a qua est illa denominatio, non est tantum obiective in mente, sed in re ipsa. Sicut quando intellectus cognoscit rem esse amatam, est quidem illud esse amatum obiective in intellectu [...]" (tamże, disp. LIV, sek. 2, art. 13). 
istnieją w nim wyłącznie przedmiotowo na mocy aktywności samego myślenia, stając się „bytami poznawczymi” refleksji intelektu ${ }^{51}$. Stają się czymś myślnym w poznaniu. Natomiast „byt myślny” jest całkowicie „bytem poznawczym”. Może on istnieć tylko w umyśle jako „przedmiot aktu intelektualnego poznania”, nigdy extra intellectum ${ }^{52}$. Zatem ten „byt poznawczy", który pojawia się w intelekcie i zależy od niego jak przedmiot od podmiotu poznającego, jest „bytem myślnym właściwym” (proprie ens rationis). Poznanie bytu myślnego, pojętego jako przedmiot w intelekcie poznającym, jest czysto przedmiotową refleksją intelektu nad przedmiotem jako przedmiotem, tzn. „bytem poznawczym”. Ten „byt poznawczy” istnieje wówczas w intelekcie jako „byt przedmiotowy” (ens obiectivum). Istnieje więc w intelekcie tak długo, jak długo trwa ujęcie poznawcze, ponieważ nie posiada on żadnego istnienia poza umysłem, tym samym w swej strukturze ontycznej i pod względem statusu istnienia różni się od bytu realnego (ens reale), który cechuje natura realna w świecie przyrody. Natomiast w poznaniu ,istnienie przedmiotowe” jest jedynie czymś zewnętrznym i akcydentalnym dla bytu realnego ${ }^{53}$. Byt myślny zatem jest tego rodzaju bytem, który nie oznacza niczego w świecie przyrody i sam w sobie nie jest bytem, ale jest tworzony i pojmowany jako byt przedmiotowy w poznaniu refleksyjnym intelektu ${ }^{54}$. Pewne wszakże konstrukcje myślowe mogą istnieć w umyśle, mimo to

51 „[...] obiective autem est in cognitione reflexa, qua intellectus cognoscit se cognoscere, vel potius qua cognoscit rem esse cognitam" (Tamże).

$52,[. .$.$] entia rationis, quia huiusmodi entia proprie solum dicuntur esse obiective$ in intellectu; unde solum sunt quando cognoscuntur aut finguntur ab intellectu" (tamże, disp. III, sek. 1, art. 10).

${ }^{53}$ "Id autem, quod sic est obiective in mente, interdum habet vel potest habere in se verum esse reale, secundum quod rationi obiicitur, et hoc absolute et simpliciter non est verum ens rationis, sed reale, quia hoc esse est quod simpliciter per se convenit, obiici autem rationi est extrinsecum et accidentale" (tamże, sek. 1, art. 6).

54 „Unde etiam per antonomasiam solent hae relationes rationis vocari res secundae intentionis, non quia omnis res cognita per intellectionem reflexam sit ens rationis, constat enim ipsam intellectionem realem posse reflexe cognosci, sed quia suum esse habet tantum obiective in secunda seu reflexiva cognitione intellectus" (tamże, disp. LIV, sek. 6, art. 10). 
odnoszą się do bytów realnych posiadających prawdziwe i realne istnienie w świecie przyrody (veram et realem existentiam). To wszakże, co na sposób „czystego przedmiotu” istnieje w umyśle, jest właściwie i wyłącznie określane bytem myślnym (ens rationis) bądź „bytem czysto poznawczym" (pure esse cognitum). Innymi słowy, w swej strukturze esencjalnej posiada on tylko istnienie przedmiotowe (existentia obiecti$v a) \mathrm{w}$ intelekcie aktualnie poznającym ${ }^{55}$.

\section{3. „REALNOŚĆ ISTOTOWA” JAKO POJĘCIE JEDNOZNACZNE} MIĘDZY BYTEM STWORZENIA A BYTEM BOGA

Odpowiednie rozumienie „bytu przedmiotowego” pozwala Suárezowi na wyrażenie w jednym pojęciu podobieństwa zarówno między bytem substancji a bytem przypadłości, jak i między Bogiem a stworzeniem (in conceptu communi). Podobieństwo to realizuje się w aspekcie poznawczym (similitudinis cognitio) na płaszczyźnie bytowości ujętej pojęciowo i najogólniej, nigdy zaś przez jednoznaczność istoty ${ }^{56}$. Realizuje się na poziomie najwyższego porządku poznania (in ordine ad nostrum modum concipiendi), jakim jest ujęcie bytu w porządku przedmiotowym. Chodzi tu bowiem o pewnego rodzaju (aliquo modo) ujęcie transcendentalnej własności bytu, a mianowicie ujęcie „realności bytowej” od strony noetycznej intelektu, przedmiotowej. Podobnie Suárez pojmu-

$55,[. .$.$] huiusmodi entia proprie solum dicuntur esse obiective in intellectu; unde$ solum sunt, quando cognoscuntur aut finguntur ab intellectu”; „[... entia rationis, qui solum habent esse obiective in intellectu" (tamże, disp. II, sek. 1, art. 1). Zob. także disp. LIV, sek. 2, art. 2; disp. VIII, sek. 2, art. 20; disp. XXV, sek. 1, art. 5.

56 „[...] docet ens, licet analogice dicatur de Deo et creaturis, intrinsece de illis dici; et per se quidem notum videtur non posse aliquid esse reale ens per denominationem extrinsecam; nam haec est propria ratio vel fundamentum entium rationis, ut postea dicetur; necesse est ergo ut quod est ens reale, sit tale realiter ac formaliter per suam intrinsecam entitatem, quae est idem cum ipso, et inseparabilis ab ipso, etiam si reliqua omnia ab eo [...]" (tamże, disp. II, sek. 2, art. 18). 
je inne zasady transcendentalne, jak „jedno” czy „prawdę"57. Ich poznanie w metafizyce w istocie sprowadza się do poznania niedyskursywnych zasad (prima principia) jako zasad formalnie przynależnych do bytu. Przy czym ich poznanie odbywa się na płaszczyźnie przedmiotowej intelektu, który umożliwia wgląd w najgłębszą strukturę esencjalną bytu, najbardziej idealną ${ }^{58}$. Chodzi zatem o takie rozumienie „realności”, w którym „realność” staje się istotą bytu, która na sposób jedności bytowej wiąże transcendentalnie wszystkie byty in communi i stanowi wewnętrzną zasadę bytu zarówno w odniesieniu do bytu stworzonego, jak i Boga, bytu w możności, jak i w akcie ${ }^{59}$. Wyrażona w intelekcie na sposób idealnej jedności transcendentalnej („realność bytowa”), wskazuje na jedną rację istnienia bytu, którą jest „istota”. Będąc zarazem naczelną zasadą bytowości, „realność istotowa” warunkuje wszystkie działania i własności wszystkich bytów (jest ratio entis) ${ }^{60}$. „Realność” jest bowiem podstawą wszystkich bytów, zarówno tych w możności, jak i w akcie, tych w intelekcie poznającym, jak i wszystkich substancji ${ }^{61}$.

57 Tamże, disp. III, sek. 1, art. 1.

58 Tamże, disp. III, sek. 1, art. 11.

59 „Una vero dubitatio circa duas conclusiones positas hic praetermitti non potest, quamvis attingat divisionem entis in ens in actu et ens in potentia; scilicet, an illa duplex significatio entis nominaliter et participialiter sumpti sit mere aequivoca, vel ita analoga ut nullus conceptus communis utrique membro ei respondeat, an vero habeat aliquem conceptum communem; nam si hoc posterius dicatur, nondum est a nobis communissima ratio entis satis explicata" (Disputationes metaphysicae, disp. II, sek. 4, art. 8 (Ens in actu et in potentia in quo conveniant).

60 „Primo modo dicimus, essentiam rei esse id quod est primum et radicale, ac intimum principium omnium actionum ac proprietatum quae rei conveniunt, et sub hac ratione dicitur natura uniuscuiusque rei, ut constat ex Aristot., V Metaph., text. 5; et notat D. Thomas, De Ente et Essentia, c. 1, et Quodl. I, a. 4, et saepe alias. Secundo autem modo dicimus essentiam rei esse quae per definitionem explicatur, ut dicit etiam D. Thomas, dicto opusculo De Ente et Essentia, c. 2, et sic etiam dici solet illud esse essentiam rei quod primo concipitur de re" (tamże, disp. II, sek. 4, art. 6).

61 „Evasio refellitur. - Fortasse aliquis respondebit non esse convenientiam realem inter omnia entia in ratione entis, sicut est inter omnes substantias in ratione substantiae, vel inter accidentia in ratione accidentis. Sed, vel est sensus inter entia ut sic nul- 
Odwołanie się w poznaniu do istoty, a więc „bytowości realnej” pojętej jako zasada transcendentalna, umożliwia Suárezowi przeniesienie obiektywnej struktury bytu, którą jest „realność”, na płaszczyznę intelektu, którego akty również są realne. Dla Suáreza w bycie realnym dochodzi do wyrażenia „relacji transcendentalnej” (relatio transcendentalis), która - jako racja istotowa - jest relacją względem istnienia (secundum esse), podobnie jak relacja kategorialna względem intelektu (se-

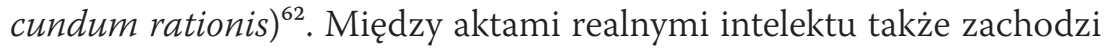
relacja transcendentalna ${ }^{63}$.Zatem między bytami realnymi istnieje pewna proporcjonalność realna. Natomiast między bytami czysto poznawczymi (byty myślne), których esse est cognosci, zachodzi tylko „relacja myślna" (relatio rationis) ${ }^{64}$. W aspekcie realnej denominacji dochodzi do przeniesienia realnej struktury bytu na poziom intelektu, albowiem w akcie „denominacji” intelektu, która jest intelektualnym ujęciem rzeczy przez opis (ujęciem zapośredniczonym przez pojęcia), zawiera się

lam esse realem convenientiam, vel non esse tantam quanta est inter alia... per suam intrinsecam entitatem, quae est idem cum ipso, et inseparabilis ab ipso, etiam si reliqua omnia ab eo praescindi vel separari intelligantur; et ita etiam accidentia, licet entitas substantiae ab eis separetur, intelliguntur intrinsece retinere suam entitatem, qua sunt entia realia [...]" (tamże, disp. II, sek. 2, art. 18).

62 "Tertio ac praecipue dividitur relatio realis et secundum esse, in transcendentalem et praedicamentalem, quae divisio maxime necessaria est ad concludendum et declarandum id quod in praesenti sectione intendimus. Hactenus enim solum constat, relationem pertinentem ad hoc praedicamentum, Ad aliquid, debere esse realem et secundum esse” (Disputationes metaphysicae, disp. XLVII, sek. 3, art. 10); „Quinimo verisimile est, in entibus creatis nullum esse ita absolutum, quin in sua essentia intime includat aliquem transcendentalem respectum, saltem quatenus est ens per participationem, per se essentialiter pendens ab ente per essentiam. Nam, licet ipsa actualis dependentia sit aliquid ex natura rei distinctum ab ipso ente creato, tamen ipsa aptitudo et necessitas dependendi est intrinseca et essentialis illi; non videtur autem posse concipi, aut esse sine transcendentali respectu et habitudine ad illud a quo pendet, in quo respectu maxime consistere videtur potentialitas et imperfectio entis creati ut tale est" (Disputationes metaphysicae, disp. XLVII, sek. 3, art. 13). Również disp. LIV, sek. 2, art. 10.

${ }^{63}$ Tamże, disp. XLVII, sek. 3, art. 2, 11-13, 18.

${ }^{64}$ Tamże, disp. LIV, sek. 6, art. 7; disp. XLVII, sek. 15, art. 13. 
realne odniesienie do konkretnego przedmiotu tej denominacji, który posiada ontologiczny status bytu realnego ${ }^{65}$. Wobec czego denominacja ta nie jest czysto myślną denominacją, która zachodzi w wypadku relacji myślnych między bytami poznawczymi (entia cognitum), lecz jest denominacją realną. Odwołanie się do zasady transcendentalnej bytu („realności”) pozwala zatem Suárezowi na wyrażenie w jednym pojęciu (na sposób jedności intelektu) jednej doskonałej „istoty”, niezróżnicowanej przez determinacje poszczególnych bytów, ich nacechowanie przypadłościowe. Wszystkie poszczególne byty pod względem „realności” są identyczne ${ }^{66}$. Ujednolicenie zatem pojęcia bytu w aspekcie „realności bytowej" pozwala na uchwycenie w jednym, uprzedmiotowionym pojęciu najgłębszej istoty bytu (aliquam communem rationem seu conceptum communem ${ }^{67}$. Skoro „realność” jest istotą wszelkiego bytu, musi być zarazem zasadą pierwszego i najdoskonalszego ze wszystkich bytów - bytu Bożego.

Należy zwrócić szczególną uwagę na fakt, że nawet dla teologii istota Bożej substancji nie jest całkowicie poznawalna. Bóg nie jest adekwatnym przedmiotem nawet nadnaturalnej teologii, która w istocie nie koncentruje się na poznaniu Boga, ale bytu realnego. Teologia, dla której Objawienie Boże (Divina Revelatio) stanowi rację formalną przedmiotu, kieruje się w stronę zasad, w tym zasad poznania (ratione cognoscendi), które przynależą do wszystkich rzeczy, w Bogu zaś są od-

$65,[. .$.$] relatio sine alia causalitate, solum quia ex intrinseca sua essentia respicit$ terminum, illum denominat terminantem. Sicut visio denominat rem visam sine vera causalitate, sed ex eo solum, quod est cum tali intrinseca habitudine; unde sicut non prius natura est quam habeat illam habitudinem, ita non prius natura est quam denominet objectum visum" (tamże, disp. XLVII, sek. 16, art. 25).

66 Założenia Suáreza prowadzą do wykluczenia teorii „aktu i możności”. Niektórzy komentatorzy dopatrują się w jego monistycznej koncepcji „istoty” wyraźnych przesłanek dla „panteizmu”. Por. M. Borzyszkowski, Koncepcja bytu w metafizyce Suareza, „Studia Warmińskie” 1 (1964), s. 399, 405; R. Garrigou-Lagrange OP, La distinction réelle d'essence et existence et le principe d'identité, „Revue des Sciences Philosophiques et Theologiques" 3 (1909), s. 308-313.

${ }^{67}$ Disputationes metaphysicae, disp. II, sek. 4, art. 9. 
najdywane w stopniu najwyższym ${ }^{68}$. Poprzez Objawienie, które w sposób nadprzyrodzony odkrywa je w Bogu i stworzeniu, teologia poznaje, że wszystkie zasady, zarówno poznania, jak i bytu, są pierwsze względem Boga ${ }^{69}$. Człowiek zbliża się do Jego poznania poprzez rozważanie zasad bytu (ratio entis) we wszystkich aspektach bytowego odniesienia, skończonym i nieskończonym. Z drugiej strony, idea Boga poddaje intelektowi myśl o realnym istnieniu, co sprawia, że w metafizyce Suáreza „realność” stanowi konstrukcję wszelkiego bytu, zarówno stworzonego, jak i niestworzonego. Ze względu na „realność” ustala się granice rzeczy i poznania prawdziwego, klasyfikuje substancje w gatunki i rodzaje. „Realność” jest podstawą niesprzeczności poznawczej w granicach bytu i nie polega jedynie na nominalnej zgodności własności logicznych. Te mogą w równym stopniu odnosić się do dialektyki, jaką posługujemy się w ontologii bytu myślnego, bytu nie-realnego. Myślenie o bycie nie pozwala zatem na swobodę w zestawianiu treści przypadkowych, ale na konieczne rozgraniczenie treści sztucznych (fikcyjnych) od realnych, co ostatecznie pozwala na umiejętne badanie bytu od strony „realności bytowej”, transcendentalności. Tylko „realność” ustala granice rzeczy i adekwatne definiowanie istoty bytu. „Realność” nie jest bowiem wytworem umysłu ani rzeczą sztuczną, ale rdzeniem bytowości. „Realność” - jak wynika z koncepcji bytu Suáreza - jest dostosowana do rzeczy istnieją-

68 „Quamquam nec de supernaturali theologia constet solum Deum esse obiectum adaequatum illius; multi enim censent non Deum, sed ens revelatum esse obiectum adaequatum illius doctrinae; quia divina revelatio, quae est ratio formalis sub qua illius obiecti, aeque cadere potest in Deum et res alias, quod attinet ad vim et rationem cognoscendi, quamvis in ratione finis et in excellentia rei revelatae Deus omnia superet, et ideo dici soleat vel principale obiectum, vel simpliciter obiectum, practice et in ordine ad mores res considerando" (tamże, disp. I, sek. 1, art. 12).

69 „Neque ad huiusmodi obiectum adaequatum constituendum, quod Deum sub se comprehendat, necesse est dari aliquid vel aliquam rationem entis quae sit prior natura Deo, sed satis est ut detur secundum abstractionem vel considerationem intellectus, quod non repugnat, ut infra ostendemus tractando de conceptu entis. Sicut enim intelligi potest convenientia aliqua vel similitudo imperfecta inter Deum et creaturas in ratione entis, substantiae, vel spiritus, ita possunt dari aliqui conceptus secundum rationem priores Deo in universalitate praedicationis [...]" (tamże, disp. I, sek. 1, art. 13). 
cych bądź zdolnych do istnienia i wskazuje na porządek, zgodnie z którym byty istnieją. „Realność” w tym wypadku okazuje się być podłożem poznania bytu stworzonego i niestworzonego.

Przedmiotem metafizyki Suáreza jest więc uprzedmiotowione pojęcie „bytowości realnej” (ens inquantum ens reale), istoty wszelkiego bytu. Istota zawiera się analogicznie w równym stopniu w bycie „przygodnym” i „aktualnym”70. Przy analizie „bytu” w metafizyce Suáreza należy szczególnie pamiętać, że w ujęciu scholastycznym „realność” jest pojęciem szerszym niż „rzeczywistość”. Stanowi zasadniczą strukturę esencjalną bytu i konstytuuje byt wewnętrznie. Nie można zatem zgodzić się z rozumieniem Etienne Gilsona, zgodnie z którym pojęcie „bytu” u Suáreza odnosi się bardziej do „bytu aktualnego” niż „przygodnego”. Zgodnie z rozumieniem Gilsona „istota”, która jest przedmiotem właściwym ontologii Suáreza, o tyle może zostać zdefiniowana jako „byt”, o ile sama została urzeczywistniona w istnieniu. Wówczas byt posiada rzeczywistą istotę z aktualnym istnieniem. Gilson wprowadza jeszcze drugie znaczenie, według którego pojęcie „bytu” przysługuje ponadto

70 „Dicendum est ergo ens in quantum ens reale esse obiectum adaequatum huius scientiae. Haec est sententia Aristotelis, IV Metaph., fere in principio, quam ibi D. Thomas, Alensis, Scotus, Albert., Alex. Aphrod., et fere alii sequuntur, et Comment. ibi, et lib. III, comm. 14, et lib. XII, comm. 1; Avicen., lib. I suae Metaph., c. 1; Sonc., IV Metaph., q. 10; Aegid, lib. I, q. 5, et reliqui fere scriptores. Probataque est haec assertio ex dictis hactenus contra reliquas sententias. Ostensum est enim obiectum adaequatum huius scientiae debere comprehendere Deum et alias substantias immateriales, non tamen solas illas. Item debere comprehendere non tantum substantias, sed etiam accidentia realia, non tamen entia rationis et omnino per accidens; sed huiusmodi obiectum nullum aliud esse potest praeter ens ut sic; ergo illud est obiectum adaequatum" (Disputationes metaphysicae, disp. I, sek. 1, art. 3). Suárez kilkakrotnie przyjmuje na oznaczenie przedmiotu metafizyki w sposób jednoznaczny określenie „podmiotu” i „przedmiotu”. Por. Disputationes metaphysicae, disp. I, sek. 2; disp. II, sek. 4. W innych miejscach wprowadza rozróżnienie. Por. Disputationes metaphysicae, disp. II, sek. 2, art. 25; disp. VI, sek. 3, art. 12; Disputationes metaphysicae, t. 26, disp. XXXI, sek. 2, art. 8; disp. XXXI, sek. 3, art. 3; Disputationes metaphysicae, disp. LIV, sek. 2, art. 1: „Ac denique, cum in nulla re sit subiective, sed tantum obiective in intellectu, ut dictum est [...]". 
temu, co jest zdolne do istnienia jedynie rzeczywistego ${ }^{71}$. Gilson analizując pojęcie „bytu”, jego rozumienie uzależnia od rozumienia problemu różnicy między „istnieniem” a „istotą". Tym samym wydaje się on błędnie odczytywać znaczenie „istoty”, która w systemie Suáreza jest rozumiana w porządku „realności”, a nie „rzeczywistości”. Atoli te dwa pojęcia w scholastycznej terminologii mają zasadniczo odmienne znaczenia. „Ens reale” nie odnosi się wyłącznie do pojęcia „bytu rzeczywistego". Mimo iż autor w pewnym momencie zdaje się dostrzegać (przywołując interpretację Josepha Kleutgena), że u „scholastyków to, co rzeczywiste, nie utożsamia się z tym, co a ktu alne, czyli istniejące, i nie przeciwstawia się temu, co możliwe", sprowadza całą analizę bytu do zdefiniowania przedmiotu metafizyki Suáreza przez pryzmat istnienia, które stanowi kres analizy metafizycznej ${ }^{72}$. W podejściu Gilsona, skądinąd w wielu miejscach słusznym, nieodzownie narzuca się tendencja do przekształcania systemu Suáreza z „ontologii istoty” w „ontologię istnienia"73. Wbrew wszelkim oryginalnym spostrzeżeniom podejście to wydaje się niesłuszne. By przekonać się, że interpretacja Gilsona nie wydaje się tu dostatecznie uprawomocniona, wystarczyłoby zanalizowanie ścisłego znaczenia pojęcia „rzeczywistości”, które pochodzi od terminu „existentia”, jak „existens” od „existo”, a nie od „possibile esse”.

Według Suáreza akt istnienia rzeczy w sensie rzeczywistej egzystencji przysługuje temu, co posiada realny akt istnienia w znaczeniu aktualnej realności. To znaczy, że to, co istnieje w rzeczywistości, musi oznaczać rzecz posiadającą akt istnienia („existens nunquam dici potest de re quae actu non existat”) ${ }^{74}$. „Byt” i „rzecz” oznaczają tutaj dwa różne pojęcia. Pojęcie „bytu” posiada szerszy zakres desygnatów, obejmując

${ }^{71}$ Por. przeł. P. Lubicz i J. Nowak, Warszawa 1963, s. 125-126.

72 Tamże, s. 132.

${ }^{73}$ Tamże, s. 132-134. Takie samo spostrzeżenie czyni inny komentator F. Suáreza. Por. A. Aduszkiewicz, Od scholstyki do ontologii, Warszawa 1995, s. 51-52 (cenna pozycja i wciąż aktualna, w której autor omawia proces rozwoju scholastyki odrodzeniowej na tle różnych stanowisk filozoficznych).

74 „Sed ens in hac significatione non retinet vim participii, quia participium consignificat tempus, et ita significat actuale exercitium essendi seu existendi, et ideo haec 
również pojęcie rzeczy. „Byt” (ens) w formie rzeczownikowej oznacza u Suáreza „to, co jest” i pochodzi od wyrazu „sum”- „będący” (w formie verbum substantivum), który jest imiesłowem czasu teraźniejszego czasownika „esse” (być, istnieć, żyć). Tylko byt jako participium oznacza tutaj to, co aktualnie istnieje $\mathrm{e}^{75}$. Natomiast byt wyrażony w postaci pojęcia (ens ut nomen) jest pojęciem szerszym i obejmuje byt zarówno w akcie, jak i w możności. A więc byt jako participium, jak i wszelki byt w możności. Zaakcentowany przez Suáreza podwójny zakres pojęcia „bytu”, który zostaje rozciągnięty na byt rzeczy i byt w umyśle, pozwala na uchwycenie istoty bytu niezależnie od konkretnego zdeterminowania, a więc niezależnie od tego, czy byt ma charakter substancjalny, możnościowy, intencjonalny, czy też stworzony, niestworzony, skończony bądź nieskończony. Pozwala to na pominięcie zróżnicowania poszczególnych bytów w sensie ontycznym, a także na uchwycenie istoty bytu, a raczej bytu jako istoty, w jedności wspólnego pojęcia przedmiotowe-

vox, existens nunquam dici potest de re quae actu non existat, quia semper retinet vim participii verbi existere" (Disputationes metaphysicae, disp. II, sek. 4, art. 3).

75 „Ens participium quid importet. - Hac ergo supposita vocis significatione, facilis est quaestionis resolutio in communi sumpta. Dicendum est enim primo, sumpto ente in actu, prout est significatum illius vocis in vi participii sumptae, rationem eius consistere in hoc, quod sit aliquid actu existens, seu habens realem actum essendi, seu habens realitatem actualem, quae a potentiali distinguitur, quod est actu nihil. Hoc totum, cum solum consistat in declaratione simplicissimi conceptus, non potest aliter probari quam ex communi modo concipiendi et ex significatione vocis a nobis explicatae. Ac denique, quia ex dictis in praecedentibus sectionibus constare potest ens sub hac ratione posse habere unum conceptum formalem et obiectivum, communem omnibus entibus actu existentibus, cum inter se similia sint et conveniant in actuali esse et entitate, constat etiam posse conceptum illum hac voce significari; ergo entis sic sumpti et conceptus eius ratio non potest in alio consistere, nec potest aliter explicari. 5. Dico secundo: si ens sumatur prout est significatum huius vocis in vi nominis sumptae, eius ratio consistit in hoc, quod sit habens essentiam realem, id est non fictam nec chymaericam, sed veram et aptam ad realiter existendum. Probatio huius conclusionis eadem proportionaliter est quae praecedentis, quia hic simplex conceptus non potest alio modo intelligi aut explicari” (tamże, disp. II, sek. 4, art. 4-5). 
go (unitate et communitate conceptus obiectivi), wyższego niż pojęcie formalne (formalis) ${ }^{76}$.

Pojęcie „bytu-istoty” zostaje tutaj potraktowane przez intelekt w sposób przedmiotowy na podobieństwo doskonałej „jedności bytowej", stanowiącej prawdę transcendentalną bytu realnego. Dla intelektu najbardziej wyabstrahowanym pojęciem jest pojęcie „przedmiotowe”, najbardziej doskonałe. Poprzez przeniesienie pojęcia „bytu” na płaszczyznę przedmiotową, noetyczną intelektu, Suárez chce wskazać, że różnice między poszczególnymi bytami, np. między bytem stworzonym (creatum), który istnieje per participationem, a niestworzonym Bogiem (increatum), który istnieje per essentiam, ograniczają adekwatne poznanie „bytu jako bytu” (ens qua ens), gdyż ten w swej istocie jest jeden i ten $\operatorname{sam}^{77}$. Istnieje wprawdzie kryterium odróżniające byt niestworzony - Boga od stworzenia, ale ta kwestia dotyczy w metafizyce

76 „Datur una ratio entis obiectiva.- Dico ergo primo conceptui formali entis respondere unum conceptum obiectivum adaequatum et immediatum, qui expresse non dicit substantiam, neque accidens, neque Deum, nec creaturam, sed haec omnia per modum unius, scilicet quatenus sunt inter se aliquo modo similia et conveniunt in essendo. In hac conclusione conveniunt auctores secundae sententiae, et Fonseca non dissentit, et plurimum favet D. Thomas, locis supra citatis de Veritate, q. 1, a. 1, q. 21, a. 1, quatenus dicit conceptum entis esse simplicissimum et primum omnium, determinarique ad substantiam, quantitatem, etc., per quamdam determinationem et expressionem talis modi entis, ubi necesse est esse sermonem de conceptu obiectivo; nam formalis non determinatur nec contrahitur. Unde apertius I, q. 5, a. 3, ad 1, ait D. Thomas: Substantia, quantitas et qualitas contrahunt ens, applicando ens ad aliquam quidditatem seu naturam; contractio autem intelligi non potest sine aliqua unitate et communitate conceptus obiectivi” (tamże, disp. II, sek. 2, art. 8). Na temat różnicy między pojęciem "formalnym” i "przedmiotowym” (distinctio conceptus formali et obiectivi) zob. Disputationes metaphysicae, disp. II, sek. 1 (Utrum ens in quantum ens habeat in mente nostra unum conceptum formalem omnibus entibus communem), sek. 2 (Utrum ens habeat unum conceptum seu rationem formalem obiectivam).

${ }^{77} \mathrm{Na}$ temat podziału bytu na ens per essentiam i ens per participationem zob. Disputationes metaphysicae, disp. XXVIII, sek. 1, art. 13; sek. 2 (Utrum sufficienter et adaequate dividatur ens per finitum et infinitum et alia aequipollentia membra). Zob. również J. Hellín, Lineas fundamentales del sistema metafisico de Suárez, „Pensamiento" 4 (1948), s. 138-140. 
Suáreza jedynie pojęcia „zależności” (dependentia), jaka zachodzi między stworzeniem a jego Stwórcą w aspekcie istnienia („creaturam esse ens essentialiter pendent a Deo" ${ }^{78}$. Byt stworzony nie istnieje na mocy samego istnienia, lecz w sposób zależny od przyczynowości sprawczej $\mathrm{Boga}^{79}$. Istnienie stanowi jedynie nieuprzyczynowioną istotę Boga, który jest bytem koniecznym i samym aktem istnienia ${ }^{80}$. Pojęcie „bytu” zatem pod względem „jedności” i „realności” jest jedno. Tylko poznanie bytu na sposób „jedności bytowej” (unitate conceptum entis) i „realności istotowej" poprzez analogię atrybucji, która jest ważniejsza dla Suáreza niż „analogia bytowa” (analogia entis) ${ }^{81}$, pozwala na uzyskanie jedno-

${ }^{78}$ Por. Disputationes metaphysicae, disp. XX, sek. 4, art. 14-15; disp. XX, sek. 4, art. 1; disp. XXX, sek. 2, art. 16; disp. XXXI, sek. 14, art. 2; disp. XXVIII, sek. 1, art. 14. „[... creaturam esse ens quia est participatio divini esse, sic non iam definitur creatura ut ens est, sed ut tale ens est, nimirum creatum” (disp. XXVIII, sek. 3, art. 15); „Relinquitur ergo ut haec analogia seu attributio quam creatura sub ratione entis potest habere ad Deum sit posterioris modi, id est, fundata in proprio et intrinseco esse habente essentialem habitudinem seu dependentiam a Deo. De qua attributione duo ostendenda sunt. Primum, quod talis attributio vere intercedat inter creaturam et Deum; secundum, quod illa ad analogiam constituendam sufficiat. Illud prius optime probatur rationibus ex D. Thom. superius adductis, quarum summa est quia creatura essentialiter est ens per participationem eius esse quod in Deo est per essentiam et ut in primo et universali fonte, ex quo ad omnia alia derivatur aliqua eius participatio; omnis ergo creatura est ens per aliquam habitudinem ad Deum, quatenus scilicet participat vel aliquo modo imitatur esse Dei; et quatenus habet esse, essentialiter pendet a Deo multo magis quam pendeat accidens a substantia" (art. 16).

79 „Nam, ex eo quod creatura habet essentialem dependentiam a causa efficienti, colligitur non esse ens per essentiam, sed per participationem, et esse non esse de essentia eius, esseque ens finitum, et similia” (tamże, disp. I, sek. 5, art. 40).

${ }^{80}$ „Unde etiam fit, ut de his rebus, quae aliquo modo sunt entia necessaria, scientia contempletur ipsam existentiam actualem, et exercitam, quod maxime habet verum circa Deum, qui est simpliciter ens necessarium et actu existens, cuius existendi necessitas non per efficientem causam [...]" (tamże).

81 „Una est de univocatione entis, quia si ens non est univocum, illa ratio sufficit ut non sit proprie universale; quomodo autem ex dictis non sequatur esse univocum, et quid illi ad univocationem desit, infra in proprio loco est tractandum, agendo de divisionibus entis; nunc solum assero omnia quae diximus de unitate conceptus entis 
znaczności pojęcia bytu. Tylko poznanie intelektualne bytu i ujęcie na sposób „jedności bytowej”, a więc w sposób wyabstrahowany (jako idea abstracta), z pominięciem wszelkich determinacji treściowych, wprowadza w pojęcie „bytu” jedność obiektywną. Byt jest czymś jednym, tak jak pojęcie „bytu” jest jedno w intelekcie. Ta zależność dotyczy zarówno pojęcia „jedności”, na sposób której pojęcie „bytu” zostaje ujęte w intelekcie, jak i pojęcia „realności”. A zatem musi zachodzić pewna proporcjonalność, która określa podobieństwo między bytem realnym a pojęciem „bytu realnego”. Otóż cecha „realności” stanowi prawdę transcendentalną bytu i w tym szczególnym wypadku ujęcia przedmiotowego stanowi o formalnym podobieństwie wszystkich bytów w ujęciu intelektualnym duszy. Zostaje uprzedmiotowiona i przeniesiona na poziom intelektu jako ens cognitum. Nie zmienia to jednak faktu, że poznanie intelektualne nie narusza struktury ontycznej i ontologicznej bytów jednostkowych, które wiąże struktura transcendentalna poza intelektem (extra intellectum). Innymi słowy, byt realny może zostać skorelowany ze świadomością, a poprzez to istnieć w umyśle przedmiotowo. Może on istnieć przedmiotowo w intelekcie jako obiekt refleksji, posiadając przedmiotowy status istnienia w poznaniu, jednocześnie nie przestając być bytem prawdziwym, tak jak i nie tracąc natury realnej w świecie fizycznym. Jeśli przeto przedmiot jest realny, to można powiedzieć, że jego treść poznawcza w intelekcie również jest realna.

Podobnie jak „prawda”, którą można pojmować na trzech płaszczyznach: in significando (na płaszczyźnie oznaczeniowej), in cognoscendo (w poznaniu) i in essendo (w bycie rzeczy) ${ }^{82}$, tak samo byt jest jeden

longe clariora et certiora videri quam quod ens sit analogum, et ideo non recte propter defendendam analogiam negari unitatem conceptus, sed si alterum negandum esset, potius analogia, quae incerta est, quam unitas conceptus, quae certis rationibus videtur demonstrari, esset neganda" (Disputationes metaphysicae, sek. 2, art. 36). Na temat zagadnienia „prawdy” u Suáreza zob. J. F. Yela Utrilla, La verdad en la metafísica de Suárez, „Revista de Filosofía” (1948), s. 659-692.

82 „Posterior veritatis consideratio est quasi formalis, et (ut sic dicam) in actu signato, scilicet, inquirendo quidnam ipsa veritas in rebus sit, et quotuplex, et quando ad ens comparetur. In quo est rursus observandum triplicem solere distingui veritatem, scili- 
zarówno w porządku istotowym (in ordine essendi), jak i poznawczo-oznaczeniowym (in ordine significandi). W swojej wewnętrznej istocie i w pojęciu „istoty” byt odnosi się do „jedności”, „realności” i „prawdziwości” w tym samym stopniu. W kontekście rozumienia prawdy przez Suáreza uwidacznia się zatem szersze znaczenie pojęcia „bytu”. Wyszczególnione trzy porządki istnienia „prawdy” pod pewnym względem (aliquo modo) charakteryzują byt od strony istotnego podobieństwa. Wyznacza je pojęcie „re a l n o ś c i”, która stanowi prawdę transcendentalną i najbardziej fundamentalną własność bytu ${ }^{83}$. Suárez pozostaje tu wierny tradycji arystotelesowsko-tomistycznej. Prawda i byt są konwertybilne, albowiem odsłanianie prawdy odsyła do bytowości samego przedmiotu, a więc do „realności” i „jedności’ istotowej. Przy czym prawda polega na wewnętrznej zgodności treści bytowej („realności”) z „intelektem”, jest ona prawdą zarówno od strony istnienia, poznania, jak i oznaczania. To samo wyraża ona od strony rzeczy oznaczanej (rem significatam), jak i od strony sądu oznaczającego (propositionem signi-

cet, in significando et cognoscendo et in essendo. Prima veritas proprie reperitur in vocibus vel scripturis, aut etiam in conceptibus quos non ultimatos vocant. Secunda est in intellectu cognoscente res, seu in cognitione et conceptione ipsarum rerum. Tertia est in rebus ipsis, quae ab illa denominantur verae. Prima igitur veritatis consideratio ad dialecticum pertinet; secunda ad physicum, quatenus de anima eiusque functionibus considerat; tertia vero est propria huius scientiae, quae tractat de ente in quantum ens et de passionibus entium. Tamen, quia omnes hae veritates inter se habent convenientiam aliquam vel proportionem" (tamże, disp. VIII, prol.). Suárez dodaje także czwarte znaczenie prawdy - „prawdę moralną”. Por. F. Suárez, Tractatus de Divina Substantia, [w:] Opera omnia, dz. cyt., t. 1, ks. I, c. 8, art. 1; tenże, Tractatus de fide, [w:] Opera omnia, dz. cyt., t. 12, ks. I, disp. 3, sek. 4, art. 1.

${ }^{83}$ „Tamen, quia omnes hae veritates inter se habent convenientiam aliquam vel proportionem, ratione cuius melius intelligentur, si simul de omnibus disputetur et quomodo inter se differant declaretur, ideo de omnibus hoc loco dicemus; sic enim facilius constabit quid sit veritas, quae proprietas entis esse dicitur. Maxime quia omnis alia veritas, si realis sit, aliquo modo sub veritate transcendentali continetur; si autem sit rationis, per analogiam et proportionem ad veritatem realem declaranda est" (tamże, disp. VIII, prol.). 
ficantem $)^{84}$. Można powiedzieć, że „realność”, „jedność” i „prawda” to szczególne modi bytu (modi entis). Dlatego też prawdę, transcendentalia poznaje się na gruncie filozofii bytu, na gruncie metafizyki.

Adekwatnym przedmiotem zesencjalizowanej metafizyki Suáreza jest uprzedmiotowione pojęcie „bytu”. Ściślej, metafizyka przyjmuje za wiodące rozważanie bytu pojętego jako „istota”, a więc „realność bytowa" ujęta pojęciowo, stanowiąca rację wszelkiego bytu (ratio entis). Tak rozumiany byt jest bytem ujętym jako ens ut nomen - posiadającym zdolność do istnienia oraz pozbawionym wewnętrznej sprzeczności $^{85}$, niewykluczającym istnienia ${ }^{86}$. Ens ut nomen wskazuje na byt, który może być bytem zarówno w akcie, jak i w możności.

Przyjęcie wykładni ontologicznej (istotowej, esencjalnej) w definiowaniu bytu pozwala Suárezowi na wprowadzenie do metafizyki takiego pojęcia, które jest pojęciem najbardziej ogólnym, o zasięgu transcendentalnym, którego jednoznaczność ujawnia się także na płaszczyźnie terminologicznej ${ }^{87}$. Jest nim nie tylko byt jako „ens ut participium” (aktualnie istniejący), ale także „ens ut nomen” (wyrażający istotę rzeczy ujętą pojęciowo ${ }^{88}$. Najogólniejsze pojęcie „bytu”, którym jest ujęcie

84 "Quoniam vero ratio nominis in principio omnis disputationis necessaria est, supponimus ex communi omnium consensu, veritatem realem consistere in adaequatione quadam seu conformitate inter rem et intellectum, sive sit conformitas intellectus ad rem, sive rei ad intellectum, quod postea videbimus, ubi latius hanc definitionem explicabimus. Hinc vero sumpta analogia vel proportione, veritas rationis seu significationis consistit in adaequatione inter propositionem significantem et rem significatam" (tamże, disp. VIII, prol.). Zob. również dzieła św. Tomasza z Akwinu: Kwestie dyskutowane o prawdzie, I, I, 3; O bycie $i$ istocie, 1; In Metaphysicam Arystotelis Commentaria, V, 9; Suma teologiczna, I, 16, 3, odp. na sprzeciw 2.

${ }^{85}$ Disputationes metaphysicae, disp. II, sek. 4, art. 7.

${ }^{86}$ Tamże, disp. II, sek. 4, art. 11.

${ }^{87}$ Por. R. Darge, Grundthese und ontologische Bedeutung der Lehre von der Analogie des Seienden nach F. Suárez, [w:] „Philosophisches Jahrbuch”106 (1999), s. 312-333.

${ }^{88}$ Zob. Disputationes metaphysicae, disp. II, sek. 4, art. 3 (Ens et participium, et nomen) „Ens nomen quid.- Solum restabat exponendum quid sit essentia realis, vel in quo ratio eius consistat; nam cum essentia sit secundum quam res dicitur seu denominatur ens, ut Div. Thom. ait, De Ente et Essentia, c. 2, quod maxime verum est 
przez istotę (ens ut nomen), nie będąc czymś zdeterminowanym, określonym, zostaje przedstawione w horyzoncie intencjonalnym jako pojęcie przedmiotowe i mogące odnosić się do wszystkiego. A więc jako pojęcie jednoznacznie orzekające w porządku przedmiotowym intelektu (obiectivum) o substancji (substantia), bycie przypadłościowym (esse accidentalis), gatunkach, rodzajach (speciei et genui), o stworzeniach i Bogu (creaturas et Deo), bycie skończonym i nieskończonym (ens finitum et infinitum), aktualnym i możnościowym (esse actualis et potentialis), materialno-konkretnym (hoc aliquid) i niematerialnym (immateriale). Byt zatem zostaje ujęty jako przedmiotowe pojęcie wspólne wszystkim naturom realnym, gdzie pojęcie bytu „ens in communi" jest najwyższym rodzajem, najbardziej ogólnym pojęciem bytu. Byt zostaje sprowadzony do sfery przedmiotowej intelektu. Sprawia to, że nasz umysł treści odnoszące się do wybranych rzeczywistości ujmuje jakby jednym pojęciem bytu przedmiotowego (ens

de ente in hac acceptione sumpto, ideo non potest satis explicari in quo consistat ratio entis realis, nisi intelligatur in quo consistat essentia realis. In quo duo peti possunt, quae illis duabus vocibus indicantur: primum, in quo consistat ratio essentiae; secundum, in quo consistat quod realis sit. Primum non potest a nobis exponi, nisi vel in ordine ad effectus vel passiones rei, vel in ordine ad nostrum modum concipiendi et loquendi. Primo modo dicimus, essentiam rei esse id quod est primum et radicale, ac intimum principium omnium actionum ac proprietatum quae rei conveniunt, et sub hac ratione dicitur natura uniuscuiusque rei, ut constat ex Aristot., V Metaph., text. 5; et notat D. Thomas, De Ente et Essentia, c. 1, et Quodl. I, a. 4, et saepe alias. Secundo autem modo dicimus essentiam rei esse quae per definitionem explicatur, ut dicit etiam D. Thomas, dicto opusculo De Ente et Essentia, c. 2, et sic etiam dici solet illud esse essentiam rei quod primo concipitur de re; primo (inquam) non ordine originis (sic enim potius solemus conceptionem rei inchoare ab his quae sunt extra essentiam rei), sed ordine nobilitatis potius et primitatis obiecti; nam id est de essentia rei, quod concipimus primo illi convenire et primo constitui intrinsece in esse rei vel talis rei, et hoc modo etiam vocatur essentia quidditas in ordine ad locutiones nostras, quia est id per quod respondemus ad quaestionem quid sit res. Ac denique appellatur essentia, quia est id quod per actum essendi primo esse intelligitur in unaquaque re. Ratio ergo essentiae his modis potest a nobis declarari" (tamże, disp. II, sek. 4, art. 6). 
obiectivum), które są sobie bliskie z racji „jedności intelektu” ujętej na wzór „jedności bytowej”. Pojęcie „bytu” orzeka wówczas w równym stopniu o jednoznaczności „Boga” i „stworzenia”, ale tylko poprzez pewną analogiczność pojęcia bytu, nie zaś z racji jednoznaczności formy. „Byt przedmiotowy”, w którym wyraża się zasadnicza treść metafizyki Suáreza, przenosząc refleksję nad bytem na poziom noetyczno-przedmiotowy, w istotny sposób ukazuje jedność transcendentalną bytu wraz z jednością pojęciową. Zarazem umożliwia ujęcie bytu niematerialnego (tu Boskiego) w intelekcie w aspekcie jego niezdeterminowanej bytowości jako bytu najdoskonalszego i najwyższej przyczyny. Wyabstrahowane pojęcie „bytu-istoty” może wówczas odnosić się zarówno do Boga, jak i stworzenia. Pod tym względem stanowisko Suáreza zbliża go do jednego z największych reprezentantów szkoły jezuickiej jego czasów, Piotra Fonseki ${ }^{89}$, jak również do szkoły neoplatońskiej, reprezentantów nominalizmu i niektórych filozofów arabskich. Stanowisko Suáreza w sprawie poznania metafizycznego zbliża go zwłaszcza do koncepcji Awicenny († 1035), Williama Ockhama († ok. 1350), Jana Buridana († ok. 1362), a przede wszystkim Jana Dunsa Szkota († 1308), który w swoim dziele Ordinatio definiuje metafizykę jako intelektualną wiedzę o bycie, zawierającym wirtualnie wszystkie inne pojęcia, również pojęcie Boga ${ }^{90}$.

\section{PODSUMOWANIE}

Z powyższych rozważań wynika, że pojęcie „bytu” oznacza dla Suáreza „istotę" ujętą w aspekcie "realności” wyabstrahowanej (praecisive

\footnotetext{
89 Zob. K. Gryżenia SDB, Arystotelizm i Renesans. Filozofia bytu Piotra Fonseki, Lublin 1995, s. 110-114.

${ }^{90}$ Por. E. Zieliński, Jednoznaczność transcendentalna $w$ metafizyce Jana Dunsa Szkota, Lublin 1980, s. 151-153. W sprawie ujęcia bytu przez Jana Burydana zob. Z. Włodek, Koncepcja metafizyki według Jana Burydana, [w:] „Studia Warmińskie” 9 (1972), s. 215-229.
} 
tantum abstrahendo) i sprowadzonej do pojęcia przedmiotowego (coneptus obiectivus) ${ }^{91}$.

W obrębie tak pojętego przedmiotu mieści się pojęcie stworzenia i Boga. Przedmiotem metafizyki Suáreza okazuje się zatem być najogólniejsze pojęcie „bytu” (obiectum huius scientiae esse ens reale in tota sua latitudine $)^{92}$, zawierające następujące desygnaty: 1) najwyższe pojęcie bytu jako rodzaju, a więc najogólniejsze pojęcie bytu jako bytu (ens qua ens), 2) jego istotności transcendentalne (passiones entis), 3) byty stworzone (creatura) i w możności (in potentia esse), 4) byty duchowe (creatura spiritualis), 5) oraz to, co fundamentalne i transcendentne, stanowiące akt czysty (actus purus), niezdeterminowaną przyczynę wszystkiego (causa sui) - Boga. Poprzez ujęcie istotowe, uprzedmiotowione pojęcie „bytu”, rozumienie przedmiotu metafizyki staje się bardzo szerokie. Dla Suáreza - inaczej niż czynił to np. Henryk z Gandawy († 1293), według którego dwóm odrębnym rzeczywistościom odpowiadają dwa odrębne ujęcia poznawcze i różne pojęcia „bytu” „byt” oznacza obiektywną realność wspólną zarówno bytowi substancji, jak i bytowi przypadłości, bytowi w możności, jak i bytowi w akcie. Jakkolwiek jedność ta jest jedynie jednością pojęciową, jednością abstrakcyjną (ratio communis ut abstracta sit in se una), albowiem między Bogiem a stworzeniem zachodzi nieprzekraczalny dystans ontyczny ${ }^{93}$. Pojęcie „realności” pozwala wprawdzie poprzez analogię atrybucji na zachowanie w przedmiotowym pojęciu „bytu” wspólnoty nazwy „byt” między Bogiem a stworzeniem, to jednak pełna wspólnota treści istotowych nie zostaje zachowana ${ }^{94}$.

91 „Cum dictum sit ens dicere unum conceptum obiectivum, oportet in quo eius formalis seu essentialis ratio consistat [...]" (Disputationes metaphysicae, disp. II, sek. 4, art. 1).

92 Tamże, disp. I, sek. 1, art. 3.

93 Tamże, disp. XXVIII, sek. 3, art. 21.

94 „Analogia proportionalitatis propria non est inter Deum et creaturas.- Ad hanc ergo analogiam necesse et ut unum membrum sit absolute tale per suam formam, aliud vero non absolute, sed ut substat tali proportioni vel comparationi ad aliud. At vero in praesenti hoc non intercedit, sive rem ipsam, sive nominis impositionem consideremus. 
Owa analogia atrybucji, która różni się od analogii proporcjonalności niewłaściwej (impropriae), czyli metafory (stosowanej również w ontologii bytu myślnego ${ }^{95}$, jest jedynie wyartykułowaniem w struk-

Creatura enim est ens ratione sui esse absolute et sine tali proportionalitate considerati, quia nimirum per illud est extra nihil et aliquid actualitatis habet; nomen etiam entis non ideo est impositum creaturae, quia servat illam proportionem seu proportionalitatem ad Deum, sed simpliciter quia in se aliquid est et non omnino nihil; immo, ut infra dicemus, prius intelligi potest tale nomen impositum enti creato quam increato. Denique omnis vera analogia proportionalitatis includit aliquid metaphorae et improprietatis, sicut ridere dicitur de prato per translationem metaphoricam; at vero in hac analogia entis nulla est metaphora aut improprietas, nam creatura vere, proprie ac simpliciter est ens; non est ergo haec analogia proportionalitatis vel solius, vel simul cum analogia attributionis; restat ergo ut si est aliqua analogia, illa sit alicuius attributionis; atque ita tandem docuit [...]" (tamże, disp. XXVIII, sek. 3, art. 11).

95 „Quod maxime verum est de denominatione illa quae solum per analogiam sumi dicitur ex proportione vel habitudine ad aliud; nemo enim dixerit sanitatem ut sic esse proprietatem cibi aut urinae, vel risibilitatem esse proprietatem prati florentis, quia haec praedicata solum quasi metaphorice conveniunt illis subiectis" (Disputationes metaphysicae, disp. VIII [An veritas per prius dicatur de veritate cognitionis quam de veritate rei, et qou modo], sek. 7, art. 21); „Dices: quamvis haec praedicata quoad impositionem vocum sint metaphorica, tamen revera significant quasdam proprietates earum rerum quibus attribuuntur; et hoc modo sanitas dici potest proprietas talis cibi non quoad ipsam formalem sanitatem, sed quoad id quod per talem denominationem sani declarari intenditur. Sed contra, nam hinc saltem recte colligimus sanitatem non esse proprietatem cibi distinctam ab illa quae per talem metaphoram declaratur; quod si illa non esset proprietas sed essentia ipsius cibi, certe sanum non significaret proprietatem sed essentiam cibi. Sic ergo in praesenti, si verum tantum dicitur de rebus per analogiam et extrinsecam denominationem a veritate intellectus, interrogo quid indicetur vel significetur in ipso ente per hanc metaphoram vel habitudinem. Aut enim indicatur sola rei entitas, et sic verum non est proprietas entis sed solum differt ab illo quod verum metaphorice significat id quod ens significat cum proprietate; sicut ridere non est in prato alia perfectio ab ea quae est esse viride vel floridum, sed est eadem metaphorice significata. Aut per illam veri appellationem analogam indicatur in ente aliquid ab entitate diversum; et de hoc inquirimus quid sit et an sit sola denominatio extrinseca; nam, si ita est, non poterit esse proprietas entis; si autem est aliquid ultra denominationem extrinsecam, quoad id ratio veri intrinseca erit, quidquid sit de impositione vocis, an ab extrinseco desumpta sit” (tamże, sek. 7, art. 22). „Denique omnis vera analogia proportionalitatis includit aliquid metaphorae et improprietatis, si- 
turze pojęcia „bytu” (pojętego jako „realność bytowa”) tylko pewnego momentu istoty wspólnej, pewnego jej przejawu. Nie stanowi natomiast pełnej definicji „istoty”. W przeciwieństwie do Kajetana Suárez wykazuje, że jedynie analogia atrybucji może wprowadzać wspólne pojęcie „bytowości realnej” dla bytu stworzonego (creatum) i niestworzonego $(\text { increatum })^{96}$. Stanowisko Kajetana w sprawie analogii proporcjonalności jest dla Suáreza nie do przyjęcia. Jest to bowiem prawdziwa zależność, nie metaforyczna, albowiem zarówno byt stworzony, jak i byt Boski zawierają element istnienia (esse). Jednoznaczność, która zachodzi między Bogiem a stworzeniem w przedmiotowej reprezentacji bytu, jest jednoznacznością nazwy (oznaczeniową) i analogią atrybucji ujętą pod względem jednej determinacji - „realności bytowej" 97 . W definicji bytu przedmiotowego zostaje więc skonceptualizowana realność bytu stworzonego, analogicznie do realności zawartej w Bogu, którą ujmujemy pojęciowo, choć w samym Bogu odnosi się ona do istnienia (esse). Pojęcie zatem „realności” jest w tej koncepcji tylko tożsamością funkcji między Bogiem a stworzeniem, nie zaś pełnej natury. Chociaż wskazanie tej jedności jest tylko prostą

cut ridere dicitur de prato per translationem metaphoricam; at vero in hac analogia entis nulla est metaphora aut improprietas, nam creatura vere, proprie ac simpliciter est ens; non est ergo haec analogia proportionalitatis vel solius, vel simul cum analogia attributionis; restat ergo ut si est aliqua analogia, illa sit alicuius attributionis; atque ita tandem docuit D. Thom., I, q. 13, a. 5 et 6, et I cont. Gent., c. 34, q. 7 de Potent., a. 7, et In I, in prolog., q. 1, a. 2, ad 2" (Disputationes metaphysicae, disp. XXVIII, sek. 3, art. 11). Zob. Disputationes metaphysicae, disp. XXVIII, sek. 3, art. 4; disp. XXXII, sek. 2, art. 13; disp. XXXIX, sek. 3, art. 1; disp. XXXIX, sek. 3, art. 12.

96 „Quod ut declaremus, dubitari potest primo an haec analogia sit proportionalitatis an proportionis. Multi enim existimant esse proportionalitatis tantum, ut Caietanus et alii. Et revera, qui negant unum conceptum entis coguntur ita sentire, nisi velint dicere accidens esse ens per solam extrinsecam denominationem, quod absurdissimum est. Alii vero utrumque analogiae modum hic admittunt. Ego vero idem censeo hic esse dicendum quod de ente communi ad Deum et creaturas dictum est, hic, scilicet, non intervenire proprie analogiam proportionalitatis, sed attributionis tantum" (Tamize, disp. XXXII, sek. 2, art. 12). Zob. też art. 13.

97 Tamże, disp. XXVIII, sek. 3, art. 12. 
analogią, która może również zbliżać do metafory ${ }^{98}$, to jednak zaakcentowanie „realności” odsyła do intuicji pojęcia bytu zdefiniowanego sub ratione entitatis: a więc poprzez wskazanie, że „realność” jest podstawą metafizyki oraz stanowi o współzależności, niesprzeczności i prawdziwości wszystkich twierdzeń metafizycznych odnoszących się do bytu stworzonego, jak i Bożego. Ponadto Suárez zdaje się nawet przyjmować w pewnym momencie pojęcie „bytu zmniejszonego" na oznaczenie przedmiotowego odpowiednika „bytowości realnej", która w sposób transcendentalny wiąże wszystkie byty od wewnątrz poza intelektem. Aczkolwiek na drugim poziomie poznania intelektualnego intelekt odnosi się do poszczególnych bytów na zasadzie „zewnętrznej denominacji”99. Poza tym pojęcie przedmiotowe „bytowości realnej” jest wspólne wszystkim kategoriom bytów, jakkolwiek bezpośrednio nie wskazuje na żaden konkretny byt. Jest po prostu pojęciem najogólniejszym ${ }^{100}$.

98 „Ad secundam rationem respondetur illo argumento recte probari ens non esse ex his analogis quae per metaphoram vel translationem dicuntur, non vero inde fieri nullo modo esse analogum. Nam illa conditio nominis analogi, scilicet, quod non sit commune multis ex vi unius impositionis, non est de ratione omnium analogorum, sed illorum tantum quae per metaphoram seu translationem dicuntur. Unde attente considerandum est illam analogiam translativam seu metaphoricam" (tamże, art. 22).

99 „Atque hinc etiam expedita relinquitur tertia probatio, in ea enim diminute numerantur analoga attributionis. Nam praeter ea quae per extrinsecam denominationem dicuntur de secundariis significatis, sunt alia quae intrinsece et proprie dicuntur de omnibus significatis, quae proprias habent leges et conditiones diversas ab aliis analogis, ut satis declaratum est” (tamże).

${ }^{100}$ „Datur una ratio entis obiectiva.- Dico ergo primo conceptui formali entis respondere unum conceptum obiectivum adaequatum et immediatum, qui expresse non dicit substantiam, neque accidens, neque Deum, nec creaturam, sed haec omnia per modum unius, scilicet quatenus sunt inter se aliquo modo similia et conveniunt in essendo” (tamże, disp. II, sek. 2, art. 8). Zob. także art. 9-11. „Tertium, quia fere eadem ratione qua dicitur conceptus hic obiectivus entis includere omnia prima genera, vel omnes entitates simplices, dicendus esset includere omnes entitates, quantumvis compositas, hominem, leonem, etc., secundum proprias rationes suas, quod nullus hactenus dixit" (art. 12). 
Teoria bytu Suáreza stanowi zarówno całkowite zesencjalizowanie i odegzystencjalnienie refleksji nad bytem, jak i rozwinięcie teologii naturalnej i ustanowienie Boga przedmiotem „dalszym” metafizy$\mathrm{ki}^{101}$. Poprzez zesencjalizowanie filozofii pierwszej bowiem, co wiąże się ze sprowadzeniem teorii „bytu” do rozstrzygnięć w perspektywie noetycznej, gdzie byt rozumiany jest nominalnie jako istota, Suárez sprowadza metafizykę do najogólniejszej nauki o pojęciach i zasadach bytu wyrażających jego istotę. Wyeksponowanie pojęciowo-intelektualnego charakteru eksplikacji bytu, która sprowadza metafizykę do badania rzeczywistości pośredniego, nie zaś bezpośredniego, pozwala Suárezowi na aprioryczną analizę zawartości idei „bytu”, a przez nią wyrażenie jego treści idealnych i absolutnych.

\section{THE ESSENTIALIZATION OF METAPHYSICS BY FRANCIS SUÁREZ, SJ}

\section{SUMMARY}

Disputationes metaphysicae by Francis Suárez in its assumptions returns to the classical division into real being (ens reale) and mind-dependent being (ens rationis). To put it in the theoretical structure, Suárez' theory of being is directly linked to the noetic concept of "objective being" (ens objectivum). Suárez definitely broke with a classical approach to the object of metaphysics and headed an existential reflection on being toward the essentialization. So his metaphysics is not focused on the concept of being in the aspect of existence, but is the study of abstract being as the "essence". It is an interesting theory in historical terms, but it also suggests that it can provide in-depth study of previous scholastic theories. Suárez' approach meets with the theory that clearly influenced the modern epistemology and post-Cartesian philosophy

${ }^{101}$ Więcej zob. J. Uscatescu Barrón, El concepto de metafísica en Suárez: su objeto y dominio, [w:] „Pensamiento” 51 (1995), s. 215-236, zwł. 230-233. 
as a cognitive shift towards a new subjective prospect (e.g. in se conversa), in which reflection on real being was shifted toward the subject-consciousness representation, that is, toward the noetic reflection and mentalism).

\section{KEYWORDS}

Francisco Suárez, metaphysics, objective being, real being, cognitive being, essentia, first intention, second intention, intentionality, the transformation of metaphysics, modern ontology 